Portland State University

PDXScholar

$11-1997$

\title{
Ornamental Nationalism: Indigenous Images in Porfirian Mexico, 1876-1911
}

Seonaid Valiant

Portland State University

Follow this and additional works at: https://pdxscholar.library.pdx.edu/open_access_etds

Part of the Latin American History Commons

Let us know how access to this document benefits you.

\section{Recommended Citation}

Valiant, Seonaid, "Ornamental Nationalism: Indigenous Images in Porfirian Mexico, 1876-1911" (1997). Dissertations and Theses. Paper 5485.

https://doi.org/10.15760/etd.7359

This Thesis is brought to you for free and open access. It has been accepted for inclusion in Dissertations and Theses by an authorized administrator of PDXScholar. Please contact us if we can make this document more accessible: pdxscholar@pdx.edu. 


\section{THESIS APPROVAL}

The abstract and thesis of Seonaid Valiant for the Master of Arts in History were presented 6 November 1997 , and accepted by the thesis committee and the department.

\section{COMMITTEE APPROVALS:}

Friedrich Schuler, Chair

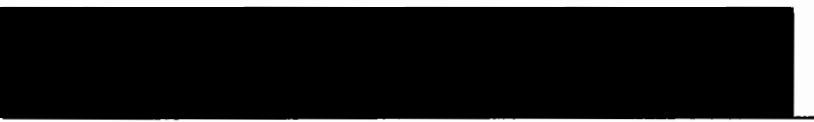

Noriko Aso

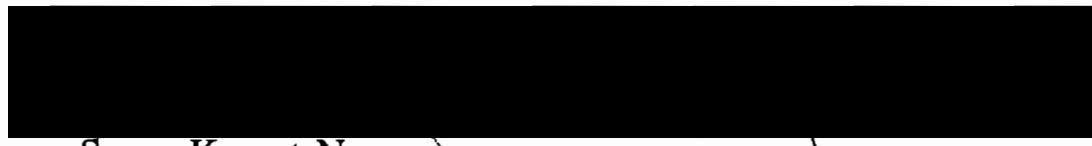

Susan Karant-Nunn

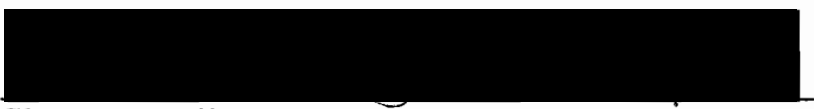

Shawn Smallman

Representative of the Office of

Graduate Studies

\section{DEPARTMENT APPROVAL:}

Gordon Dodds, Chair

Department of History

$* * * * * * * * * * * * * * * * * * * * * * * * * * * * * *$

ACCEPTED FOR PORTLAND STATE UNIVERSITY BY THE LIBRARY by

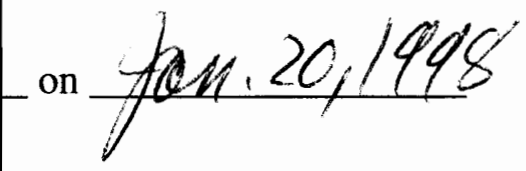




\begin{abstract}
An abstract of the thesis of Seonaid Valiant for the Master of Arts in History presented 6 November 1997.
\end{abstract}

Title: Ornamental Nationalism: Indigenous Images in Porfirian Mexico, 1876-1911.

When General Porfirio Díaz became president of Mexico the country was unstable. During his years of leadership, 1876-1911 he managed an uneven stability. One method he used to promote nationalism was the use of symbols. This thesis derives from the theory introduced by the historian of Mexican economy, Barbara Tenenbaum, that the Porfirian administrators attempted to establish themselves as the legitimate rulers of the Mexican nation by forging a line of succession from the ancient Aztecs to themselves through association with indigenous symbols and territory. The intention of this thesis is to demonstrate that the Mexican government manipulated images of indigenous peoples to inspire nationalism aimed at legitimizing Porfirio Díaz’s administration.

Chapter one discusses the domestic backdrop against which the alteration of the Aztec image took place. Chapter two discusses the international opinion regarding the Aztecs. Chapter three describes the appropriation process by which the images were manipulated through the creation of the position of the national archaeologist. Archaeological symbols leaked into federalized public art. Chapter four examines the public monuments erected bearing European and Aztec 
symbolism. Chapter five looks at Diaz's involvement in the appropriation of symbols and the public's critical attitude of the process.

An important aspect of this thesis is the evidence on which I based my ideas. The evidence is a mixture of political and archaeological writings, government reports, travel and newspaper accounts, brochures, advertisements, monuments, art works, artifacts, codices, photographs, speeches and fiestas. These various sources come from the layers of international and Porfirian society. They explain the persuasiveness of the "noble savage" image of Aztecs throughout these levels of Mexico. Through the attitudes of the upper classes these sources reveal the way in which domestically and internationally the Aztec image was sometimes embraced and sometimes rejected as a national emblem for Mexico. Ultimately, the evidence explains the failure of indigenous images as an positive international symbol for Mexico. 


\section{ORNAMENTAL NATIONALISM:}

INDIGENOUS IMAGES IN PORFIRIAN MEXICO

$1876-1911$

by

SEONAID VALIANT

A thesis submitted in partial fulfillment of the requirements for the degree of

MASTER OF ARTS

in

HISTORY

Portland State University

1997 
Acknowledgments

There are several people who assisted me with this thesis. First, I would like to thank my colleagues and friends Consuelo Lopez Portillo, Aaron Arguedes and Urusla Pike who double checked my translations. I appreciate that Faith Arbor, Monica Smith, Fredrick Nunn, Thomas Luckett, Patricia Shecter and the members of Phi Alpha Theta read early drafts of this work. Teresa Tate was particularly helpful because she recommended sources and offered comments on several drafts. My research trips to Texas and Mexico City were made possible by grants from the Friends of History and the OAA. I am grateful to the members of my committee, Noriko Aso, Susan Karant-Nunn and Shawn Smallman for their time and their comments. Most of all I owe many thanks to my advisor and mentor Friedrich Schuler for guiding me through these first steps of graduate school. 


\section{TABLE OF CONTENTS}

Acknowledgments

Introduction

Chapter I: Background

Independence, Wars of Reform, French Intervention, Indian Wars, Justo Sierra and Alfredo Chavero.

Chapter II: "The Rag Of Barbarism": Aztecs in International Thought
A. Lewis Henry Morgan
B. Exhibitions
C. Sacrifice

Chapter III: "Paradise of Speculators": Leopoldo Batres and Archaeology
A. Leopoldo Batres
B. Batres at Teotihuacan
C. Teotihuacan: Criticisms
D. La Isla de Sacrificios
E. Mitla
F. Chichén Itzá

Chapter IV: "The Invasion of Statues": Nationalism and Art

A. Europe
1. Angel of Independence
2. Semicircle to Juárez
3. Bellas Artes

B. Aztecs

1. Monument to Cuauhtémoc

2. Aztec Palace

Chapter V: Creating National and International Personality
A. Porfirio Díaz
B. Porfiriopoxtli

Chapter VI: Conclusion 
Ornamental Nationalism:

Indigenous Images in Porfirian Mexico

1876-1911.

by Seonaid Valiant

Introduction

O people of Tenochtitlan! If history has paused in amazement to contemplate your valor, how can we do less we who are sons of the land exhalted by your patriotic agony? Because of it the country you died for deserved to rise again; the very hands of your conquerors prepared the way; from your blood and theirs, both heroic, was born the nation that is proud to adopt for its own the, name of your wandering tribe, that has engraved with profound filial piety on the ensign of its eternal liberty the eagle of your primitive oracles.

-Justo Sierra ${ }^{1}$

Written three and a half centuries after the conquest of the Aztec empire the words of the historian, Justo Sierra exemplified the Mexican government's efforts to inherit the political legacy of the Aztecs. Sierra's choice of words, such as "patriotic," "liberty" and "nation" reveal more about the concerns of late nineteenth century Mexican liberals than those of the ancient Aztecs. Sierra's writings provide

${ }^{1}$ Justo Sierra, The Political Evolution of the Mexican People. Trans. by Charles Ramsdell, (Austin: The University of Texas Press, 1969), 60-2. Emphasis mine. 
a window through which to view the thirty-five years of General Porfirio Díaz's presidency, 1876 to 1911 , and its concern with unifying its nation. One attempt to do so was through the use of symbols.

This thesis derives from the theory introduced by the historian of Mexican economics, Barbara Tenenbaum, that the Porfirian administrators attempted to establish themselves as the legitimate rulers of the Mexican nation by forging a line of succession from the ancient Aztecs to themselves through association with indigenous symbols and territory. ${ }^{2}$ The intention of this thesis is to demonstrate that the Mexican government manipulated images of indigenous peoples to inspire nationalism aimed at legitimizing Porfirio Díaz's administration. My contribution to this field of history is the examination of the development of the national archaeology program which both furthered and hindered the process of manipulating images.

A key figure in Mexico's material progress Díaz also assisted in the evolution of Mexican national symbols. Through declarations, dedications and speeches Díaz glorified Aztec history. The ceremonies aimed at impressing both the domestic and international publics through the creation of a Mexican nationalist image by melding European and indigenous, mainly Aztec, symbols. The intellectual public did not always respond favorably.

${ }^{2}$ Barbara Tenenbaum, "Streetwise History: The Paseo de la Reforma and the Porfirian State, 1876-1910. Rituals of Rule, Rituals of Resistance: Public Celebration and Popular Culture in Mexico. Edited by W.H. Beezley, C.E. Martin, and W.E. French, (Wilmington, Delaware: Scholarly Resources Inc., 1994), 127-150. 
The Mexican government in this era attempted to demonstrate that it equaled the major European powers and the United States. This accomplishment would come about through a build up in investment and industry. Additionally, the creation of an archaeology program provided the ancient symbols that bolstered Mexican nationalism. This image was strengthened and emotionalized through the sanitation of symbols which people would respond to both domestically and internationally. ${ }^{3}$

Chapter one discusses the domestic backdrop against which the alteration of the Aztec image took place. The administrators Justo Sierra and Alfredo Chavero emphasized the importance of the Aztecs over other tribes but generally politicians and academics did not admire the Mesoamericans. ${ }^{4}$ The optimistic politicians, such as Sierra, believed that the remaining indigenous tribes could westernize through education. The pessimists thought that the military served as the only tool of assimilation.

The government found their adversaries to be Apaches and Yaquis in northern Mexico and Mayas in the east. The administration chose not to incorporate these groups into a usable past because they were rebellious groups. Instead they were the objects of effective military campaigns. After subduing these tribes the government implemented economic improvements in the northern areas, such as irrigation, plantation and railroad development.

\footnotetext{
${ }^{3}$ I am under the assumption that within a given society a symbol has meaning and when a political symbol is created or reinvented it is expected that people will respond to it. See, Roger Cobb and Charles D. Elder, The Political Uses of Symbols, (New York: Longman, 1983), 81-83.

${ }^{4} \mathrm{~A}$ common phrase for the tribes that lived in Mexico and Central America is "Mesoamerican,"
} 
Chapter two discusses the international opinion regarding the Aztecs. In international thought the Aztec remained a glorious savage. American popular scholars such as Lewis Henry Morgan and William H. Prescott expressed their doubts about the Mesoamericans. The administrators who employed Aztec symbols as representations of Mexico faced the necessity of sanitizing these images.

Curiosity and disdain toward the Aztecs manifested itself in traveling circus freak shows and promotional art exhibits in which disfigured people were misrepresented as Aztecs, a caricature widely accepted by the public. Even medical professionals lent credence to the idea that the Aztecs were a lesser race.

Other scholars of Aztec culture often did not unravel the complexities of Aztec life but promoted the distortions. They focused on the Aztec religious practice of human sacrifice. Due to their fascination, the scholars sensationalized the ceremonies and did not recover the lost meanings. The practice of sacrifice seemed to prove that the Aztecs were savages. Leopoldo Batres, the official Mexican national archaeologist argued for an extended political link to the Toltecs, the predecessors of the Aztecs because he believed that they did not practice human sacrifice. International politics were not immune to this attitude.

Chapter three describes the appropriation process by which the images were manipulated through the creation of the position of the national archaeologist. Archaeology was an important field for the Porfirians. First they created a law to prevent antiquities from leaving the country. Secondly Mexican archaeologists enjoyed the support of their patron Porfirio Díaz. Díaz himself had toured some of 
the sites prior to his presidency. This is the lengthiest and most important chapter because it examines the methods by which symbols were chosen or neglected by the Porfirian archaeologists.

To the outside world this appointment was meant to demonstrate that Mexico too had a superior culture and that the Mexicans were capable of resurrecting and preserving it. A national archaeological program meant to equate the ancient cultures of the Valley of Mexico to the esteemed ancestry of Greece and Egypt. According to western ideals a modern nation could only be born from a traditional country. The existence of ruins and the excavation of those sites should have placed Mexico in league with other classical countries.

Several artifacts and images from this field, including the Aztec Calendar Stone and the Pyramid of the Sun, transformed into nationalist images in this period. They have endured as enticing and patriotic images of Mexico until today. This chapter discusses the potential that existed for exploiting archaeology and anthropology for the purpose of promoting nationalism. It will become evident that Leopoldo Batres, through his domination of central sites, neglect of eastern sites and abuse of all sites made the connection between Aztecs and Porfirians more obvious and yet less convincing. ${ }^{5}$

\footnotetext{
${ }^{5}$ In determining the impact Batres had on Mesoamerican archaeology it is interesting to note the very recent view of him displayed in the Mexican National Museum of Anthropology. It is true of the museum that very few artifacts bear the names of the archaeologists who unearthed them. The museum is concerned with the preservation and exhibition of the items, not their personal histories. Alfonso Caso is not noted at the Monte Alban exhibit; Fredrick Catherwood, the first American to document Mayan ruins, is not credited for his drawings. One of the exceptions is the infamous chac mol repossessed from Augustus Le Plongeon by the Mexican government in 1875 . It bears a plaque with his name and the original location, Chichén Itzá.
} 
Archaeological symbols leaked into federalized public art. Chapter four examines the public monuments erected bearing European and Aztec symbolism. The amalgamation of images in the Monument to Cuauhtémoc and the Aztec Palace reveals two things about the government that condoned the art work. First, the government's involvement in the placement of the Monument to Cuauhtémoc on the Paseo de la Reforma constituted a federal effort to lift the public's opinion of the ancient Aztecs. Second, the careful selection and mixture of European and indigenous images suggests that the Porfirians saw themselves as Europeans ruling in America. They needed the image of the Indian to root themselves politically as Americans but also they needed European style monuments to connect themselves back to their European heritage. This connection manifested itself in the construction of a statue to the independence movement and a national theater.

The link between Mexico and Europe can clearly be seen in the monuments to the former Mexican president Benito Juárez. A lawyer and liberal politician, Juárez was the first Indian president of Mexico. The largest monument to him

Though Batres was responsible for the initial excavations at Teotihuacan there is no mention of him in either of the two rooms dedicated to the site. Likewise, at Teotihuacan, English speaking tour guides tell tourists the year in which excavations began and about the tunnel dug by Batres, but his name is never mentioned. However, as the museum's former director, Batres was not entirely forgotten.

In July, 1996, upon entering the museum one encountered a large open room. In the middle of the room was an exhibit titled, Los Lacondones Y Leopoldo Batres (The Lacondon Indians and Leopoldo Batres), One was required to walk unto a high platform and behind the title wall to view the exhibit which was small and consisted of a few Lacondon weapons and a letter from Batres. A placard informed the public that in the mid-20th century, at an advanced age, Batres lived with the Lacondones in anthropological fashion. What this means for Mexico is that Batres' work, misdeeds and successes were absorbed by the museum. The overall effect is positive. Visitors to the museum and Teotihuacan do not lament the loss of the murals because they do not know that they ever existed. In that way Batres was melded with all the archaeologists, Mexican and foreign, amateurs and experts. 
presents him as a Greek emperor. Through the venue of public art the Porfirians absorbed the political legitimacy of the Aztecs and Benito Juárez.

Chapter five looks at Díaz's involvement in the appropriation of symbols and the public's critical attitude toward the overall process. Díaz presented himself as the ring master of the independence celebrations and as a patron of archaeology. He participated in several ceremonies, including the inaugurations of the Monument to the last Aztec King and the Pyramid of the Sun. Despite Díaz's public appearances it was clear as early as 1900 that ultimately the educated population was critical of the use of Aztec images for political legitimization. The Aztecs were not respected due to their sensational religious practices and comparisons were easily drawn between Aztec human sacrifice and Porfirian military assimilation.

An important aspect of this thesis is the evidence on which I based my ideas. The evidence is a mixture of political and archaeological writings, government reports, travel and newspaper accounts, brochures, advertisements, monuments, art works, artifacts, codices, photographs, speeches and fiestas. These various sources come from the layers of international and Porfirian society. They explain the persuasiveness of the "noble savage" image of Aztecs throughout these levels of Mexico. Through the attitudes of the upper classes these sources reveal the way in which domestically and internationally the Aztec image was sometimes embraced and sometimes rejected as a national emblem for Mexico. Ultimately, the evidence explains the failure of indigenous images as positive international symbol for Mexico. 


\section{CHAPTER ONE}

\section{BACKGROUND}

The process of blending Indian with Spanish images began before Porfirio Díaz gained the Mexican presidency. Mexicans won their independence from Spain in 1821. The emblem of an eagle perched on a cactus with a serpent in its claws, an image derived from the Aztec myth regarding the foundation of their splendid city Tenochtitlan, graced the new national flag. The Aztec people were a wandering tribe who believed they would know their new homeland by this symbol. Furthermore, the Aztecs did not refer to themselves by that name but called themselves Mexica, hence the country's new name, Mexico. ${ }^{6}$ In the fifty years between independence and the dictatorship of Díaz the potential of using the Aztec images for political purposes remained unexplored. When Porfirio Díaz seized the presidential office in 1876, he used the Indian as a symbol to promote nationalism. The use of these images during the Porfiriato allowed for the expanded use of them by Lázaro Cárdenas in the 1930 's. ${ }^{7}$

${ }^{6}$ Aztec derives from Azatlan which is the mythical as yet unidentified location from which the Mexica set forth on their wanderings. Michael Meyer and William L. Sherman, The Course of Mexican History, 4th ed., (New York: Oxford University Press, 1991), 56.

${ }^{7}$ For an analysis of Cárdenas attempts to manipulate indigenous images see Marjorie Becker, Setting the Virgin on Fire: Lazaro Cárdenas, Michoacan Peasants and the Redemption of the Mexican Revolution, (Berkeley: University of California Press, 1995). 
After creating a name and a flag for the new country in 1821 , the Mexican government's stability remained in flux due to coups and factional fighting. The country survived thirty-five changes of leadership throughout these years. In the first elections after The War of Reform (1858-1861), Benito Juárez, the liberal chief of the supreme court, was chosen as Mexico's first Indian president. As president Juárez instituted anticlerical measures that which included the sale of church property to fill empty government coffers. Juárez decided that Mexico would not, indeed could not, repay the debt that the fledgling country had borrowed from England and France and this led eventually to a French military intervention in Mexico. $^{8}$

In the 1860's, Mexican political thought was divided between the conservatives and liberals. Conservatives supported the Catholic Church's role in government and longed for an imperial style of leadership. Liberal Creoles desired a republican form of government. ${ }^{9}$ Juárez's refusal to make debt payments prompted the French to invade Mexico with the backing of the Mexican conservatives. ${ }^{10}$ The Emperor, Napoleon III, sent his troops to make Ferdinand Maximilian of Hapsburg the Emperor of Mexico. His troops met with resistance at the Battle of Puebla but one year later, with the help of 30,000 reinforcements, they succeeded in their task. ${ }^{11}$

\footnotetext{
${ }^{8}$ Meyer and Sherman, 381-2.

${ }^{9} \mathrm{~A}$ Creole was a person born of Spanish parents in the New World. Racial and class definitions can be found in the text by James Lockhart and Stuart B. Schwartz, Early Latin America: A History of Colonial Spanish America and Brasil, (New York: Cambridge University Press, 1983), Chapter 4. continued.

${ }^{10}$ The US did not approve of the invasion but did not militarily interfere while the civil war ${ }^{11}$ Meyer and Sherman, 390.
} 
The conservatives expected that Maximilian would follow their instructions but instead he continued the legal reforms begun by Juárez. For instance, he decreed the return of communal lands to Native American villages. ${ }^{12} \mathrm{He}$ also promoted the arts and began the reconstruction of urban Mexico. Under Maximilian the Paseo de la Reforma became a showcase boulevard for Mexico City. Workers widened the street and built glorietas to resemble the newly constructed thoroughfares of Paris. ${ }^{13}$ Additionally, the confiscated lands were never returned to the church. As a consequence of these actions, Maximilian lost his base of support among the conservatives.

Meanwhile, Juárez retreated from Mexico City but did not concede the country to the French. Napoleon recalled French troops to France in 1867 to fight the encroaching Prussians but Maximilian remained behind with a small fighting force. Eventually, Juárez's troops regained the capital and Maximilian was executed.

In this Mexican war against the French intervention, Juárez's former law student Porfirio Díaz served as a general. ${ }^{14}$ He commanded troops with the famous General Zaragoza at several key battles, including the early Battle of Puebla. ${ }^{15}$ After Juárez's death by natural causes, General Díaz overthrew the government of Juárez's vice president Lerdo de Tejada, newly elected, and usurped the presidency from

\footnotetext{
${ }^{12}$ Meyer and Sherman, 394.

${ }^{13}$ The Parisian street was designed by Baron Georges Eugene Housman. John Lear, "Mexico City: Space and class in the Porfirian Capital, 1884-1910," Journal of Urban History, Vol. 22, no. 4 (May 1996), 466. A glorieta is a statue on a round platform in the center of the street. Typically in Mexico City, the glorieta marks the crossroads.

${ }^{14}$ Carleton Beals, Porfirio Diaz: Dictator of Mexico, (Philadelphia: J.B. Lippincott Co., 1932), 47. The Battle of Puebla is also known as Cinco de Mayo.

${ }^{15}$ Beals, 102. The Battle of Puebla is also known as Cinco de Mayo.
} 
1876-1880. In his first term he enjoyed popularity and promised he would not seek re-election. At the end of four years he returned to his home state of Oaxaca to serve as governor. In 1884 he was re-elected to the presidency. As his first controversial maneuver he altered the constitution to remove the re-election term limit. Díaz remained president until 1911 when revolutionary forces sent exiled him at the age of eighty. His reign in the Republic of Mexico is known as the Porfiriato and was marked by substantial economic, technological and artistic progress but marred by the repression of critics and indigenous peoples. ${ }^{16}$

Díaz's government was born from a violent overthrow of president Lerdo de Tejada. The situation automatically created a need for domestic and international recognition. To gain legitimacy, Díaz turned to his wealthy countrymen, foreign countries and to the ancient Aztec history of Mexico. However, Díaz's use of Aztec history seems insincere because at that time his government was busy pacifying Mexico's living Indians, particularly the Yaquis and Mayas.

The intellectual elites surrounding Porfirio Díaz were known as científicos and were from the school of French positivism. ${ }^{17}$ They believed that the Indian races were inherently backward and that assimilation into European culture would improve

\footnotetext{
${ }^{16}$ For an analysis of economic progress see John Coatsworth, Growth Against Development: The Economic Impact of Railroads in Porfirian Mexico, (Dekalb: Northern Illinois University Press, 1981).

${ }^{17}$ French ideals appealed to the Porfirians because they were economically progressive. The administrators did not look back to Spain for intellectual ideals because Spain had stagnated in the years since the conquest, secondly, Mexico had been independent for mere fifty years when Díaz took the presidency. When looking for their European heritage the Porfirians were seeking ideas that were legitimate yet new and glamorous. See Charles A. Hale. The Transformation of History in Late Nineteenth-Century Mexico, (Princeton: Princeton University Press, 1989).
} 
the Indians. The cientificos argued that societal improvement occurred through the application of scientific methods. This small group of elites participated in liberal politics since before the wars of reform. They adapted to Díaz because under him they gained positions of authority and the freedom to make policies. The most active cientifico was the lawyer and historian, Justo Sierra. Later, he would become the Minister of Public Education because his main concern was the provision of primary education. Universal and secular education would provide the means to an improved populace.

Education was the major method proposed to assimilate Indians into Mexican culture. However, congressional opponents voiced their concern that Indians would not be able to learn western ideas or science. Some congressmen believed Indians to be ignorant, backward and unable to learn non-Indian traditions. Sierra, defended the natives', "aptitude for 'assimilation, imitation and observation."18 This debate treated indigenous peoples as savages who needed to be civilized. Ironically, it would not have been possible for the Díaz administration to tap into the indigenous mythology if there had not been a certain amount of good opinion toward indigenous peoples. The editor Luis Alva promoted mixed colonies of creoles and Indians on the basis that the indigenous people were industrious, hospitable, gentle, knowledgeable (regarding their land) and the descendants of the "Great Tenochtitlan." 19 The myth of nationalism was built upon a real sentiment but the administration took advantage

\footnotetext{
${ }^{18}$ Hale, 231.

${ }^{19}$ Hale, 238.
} 
of this toleration of Indians to promote its agenda. Furthermore, the government's "indigenous pride" did not apply to those living rebellious groups in the North and the East. The situation was complex. The Porfirians were able to despise and admire the Indians because they chose the qualities they approved of and emphasized these. Another means of promoting assimilation was the use of military force. The use of images of Aztecs in the capital did not mean that indigenous groups had been fully accepted by the government or that these groups were willing to pay political tribute to the administration. Simultaneous with the dedication of the statue of Cuauhtémoc, the last Aztec leader, the Mexican government pacified the Yaquis and was involved in the Yucatan Caste War against the Mayas. ${ }^{20}$ When the administration did consider the living Indians it was with the question, could it assimilate and control them?

The Porfirians believed that if they could keep the Yaqui population in Sonora pacified they could usurp the lands. Irrigation of the Valley would then increase agricultural output and achieve the economic and technological progress they desired in that region. They believed in colonization as a method for quelling the nearly continual Yaqui rebellions. Sonora's Vice Governor wrote in 1879:

The government under my charge has decided to appeal to that of the Union, requesting its help in organizing these tribes civilly...dividing the land of their pueblos...because of successful colonization of those rivers would

\footnotetext{
${ }^{20}$ Eric Van Young, "Conclusion: The State as Vampire-Hegemonic Projects, Public Ritual and Popular culture in Mexico, 1600-1990," Rituals of Rule, Rituals of Resistance: Public Celebration and Popular Culture in Mexico, edited by W.H. Beezley, C.E. Martin and W.E. French, (Wilmington, Delaware: Scholarly Resources Inc., 1994), 355, and Tenenbaum, 136.
} 
result immediately in a great increase of the civilized population and a bountiful production in all the various branches of wealth. ${ }^{21}$

The Porfirians were hopeful that the Yaquis would be satisfied with working as sorely needed laborers and that they would relinquish their continuing demands for autonomy. It was believed that they were "..intelligent...and would become a hard working and useful people, contributing greatly to strengthen the national element on the frontier and develop the public wealth."22 The Porfirian aimed to usurp the Yaqui land and labor to benefit progress, industry and nationalism. The traditional and separate Yaqui nation these native people demanded was incompatible with Díaz's efforts to mold a Mexican nation. The process of domination required years of bloody military campaigns.

The final weapon used against Yaqui resisters was the forced exile of prisoners-of-war to the Yucatan. They were removed theoretically to use their labor on henequen plantations but more obviously to eliminate their opposition from the Yaqui Valley in Sonora. ${ }^{23}$ The number of Yaqui people relocated is unknown. ${ }^{24}$ E.H. Blichfeldt, an American traveler to the Yucatan, remarked that although the relocated Yaquis were “..industrious, peaceable and dependable," they were not

\footnotetext{
${ }^{21}$ Evelyn Hu-DeHart, Yaqui Resistance and Survival: The Struggle for Land and Autonomy, 1821-1910, (Madison: University of Wisconsin Press, 1984), 99-100. Hu-DeHart translated this passage from Jose T. Otter, "Address to the First Session of the Seventh Constitutional Congress," La Constitución, 18 September 1979, Instituto de Antropologia e Historia. Fondo de Micropeliculas. Sonora, Mexico D.F. 7.

${ }^{22}$ Translated by Hu-DeHart, Yaqui Resistance, 111. She cites, La Constitutión, 6 July 1886, 8.

${ }^{23} \mathrm{Henequen}$ is a fibrous plant, the strands of which are used to make rope.

${ }^{24}$ Evelyn Hu-DeHart, who examined reports from deportation officers and census takers reported that the figures ranged from a conservative 2757 to an exaggerated 15,000. Hu-DeHart, "Pacification of the Yaquis," in The Age of Porfirio Diaz: Selected Readings, Edited by Carlos B. Gil, (Albuquerque: University of New Mexico Press, 1977), 138.
} 
entirely sufficient workers. Blichfeldt thought, "..they are somewhat undesirable in one respect, that they die so very rapidly when brought to this climate so very different than their own."25 Blichfeldt appears to be examining the situation of the Yaqui as would an investor so welcomed by the administration. His opinion accords with that of the Porfirians who believed there would be an economic value to organizing a Yaqui labor force.

Those Yaquis who were relocated were unaccustomed to the climate but the political situation in the Yucatan was similar to that in the Yaqui Valley. These prisoners were thrust into this region at a time of political tension between Mexicans and Native Americans. The Maya in the Yucatan, like the Yaquis in Sonora, resisted Creole and ladino settlers. ${ }^{26}$ As in Sonora, political tensions often led to violent battles. These bouts were termed the "Caste War." The Spanish had never fully colonized either Northern Mexico or the Yucatan. This made it essential that the Porfirians physically and culturally assimilate the northern and eastern areas before Mexico could be considered a nation, or at the very least a controlled territory. The aggressive resistance of the Maya lasted almost until the end of Díaz's tenure. The Caste War raged until 1910 before General Bravo finally subjugated the Maya. ${ }^{27}$

Contemporary Indians were considered a problem and were not accredited any prestige by the Porfirians. However, Justo Sierra's defense of Indian people

\footnotetext{
${ }^{25}$ Both quotes are from E.H. Blichfeldt, A Mexican Journey, (Chautauqua, NY: Chautauqua Press, 1919), 51-52.

${ }^{26} \mathrm{~A}$ ladino was a person of mixed Indian and Spanish ancestry or an Indian who had become assimilated into Spanish culture.

${ }^{27}$ Nelson Reed, The Caste War of Yucatan, (Stanford: Stanford University Press, 1964), 229-249.
} 
embodied a note of nationalism. He argued that the inherent capabilities of the [Indian] races could not be questioned. Doing so would be condemning, “..to perpetual ostracism this race to which we owe part of our blood and part our glories." ${ }^{28}$ Why then, if the pervasive, upper class, attitude toward indigenous people was negative did the Porfirian government publicly dedicate and display a statue of the riotous Cuauhtémoc who had been hanged by the order of the Spanish conqueror Hernan Cortes or build an Aztec temple in Paris?

One reason for this focus on the Aztecs rather than other tribes, such as the Yaqui was that their former city lay under modern day Mexico City. After the final battles of the conquest a Spanish style city was slowly erected in the same location as the Aztec city, Tenochtitlan. ${ }^{29}$ Naturally, the Porfirians inherited the history of the Aztecs.

That the Porfirians believed, or at the very least wanted Mexicans to believe, that the Aztecs were "nationalistic" is evident. Sierra, the man charged with the Ministry of Public Education, published a history of the Mexican nation, titled, The Political Evolution of the Mexican People. Sierra was one of the few administrators who promoted the virtues of the Indian. His history served as a romantic role model for modern Mexican politics. Sierra created an Aztec sense of nationalism for a Mexican audience. It was necessary for Sierra to weave this version of history because the common view, expressed by the editor of El Monitor, held that the

\footnotetext{
${ }^{28}$ Hale, 231.

${ }^{29}$ Prescott, 628-29.
} 
Indian people did not have a sense of patriotism. "Since the idea of patria does not exist in the indigenous past it is impossible for the Indians to rise up in the name of this idea." ${ }^{30}$ As Sierra developed a myth in which the Aztecs were patriotic, it seemed appropriate for nationalistic Porfirians to turn to the Aztec heritage for emblems. In his history, Sierra, portrayed the defenders of Tenochtitlan as nationalistic warriors. In his discussion of the Spanish conquest he depicted the kidnapping of the Aztec King, Moctezuma, by Cortes, asserting that Moctezuma's capture invoked in the Aztec people an overwhelming love of their country, "For the Mexica...the divine image of the fatherland took the Emperor's place on his vacant throne." Sierra's Aztecs held such a strong love of their "nation" that they fought until, "..they hardly had the strength to wield the macana, the national sword..."32 and as they fought they suffered in "patriotic agony." chosen by Sierra is that he was an official voice of the government. Sierra may have believed that the Aztecs thought about themselves in eighteenth and nineteenth century terms like "nationalism," "patriotism," and "fatherland" but most likely he wanted the Mexican public to believe that the Aztecs thought in this way. This is not to say that the Aztecs had no sense of loyalty to family, tribe and government but that they would have thought about these ideas differently, not in terms of European progressivism. Sierra's ideas about the Aztecs sense of patriotism belong to the

\footnotetext{
${ }^{30}$ Hale, 224. He cites Enrique Chávarri , "Juvenal," El Monitor. 25 Jan. 1878.

${ }^{31}$ Sierra, 60-1. Emphasis mine.

${ }^{32}$ Sierra, 61-2. Emphasis mine.

${ }^{33}$ Sierra, 61-2. Emphasis mine.
} 
nineteenth century when these ideas were emerging. His portrayal of the Aztecs provided a model for modern patriotic devotion. This sentiment was lacking in Porfirian Mexico and his version of the Aztecs attempted to create a stronger national bond in the general public.

Sierra's history emphasized how more virtuous he believed the Aztecs were in comparison with other Indigenous groups. Another text in which the Aztecs were given preference above other tribes was in the official history of Mexico. Volume one of México a Traves de los Siglos was written by the archaeologist, historian and romance author, Alfredo Chavero. Chavero completed his pre-Hispanic history by 1889 knowing that it could be sent to the World's Fair in Paris in 1900. His volume emphasized the romantic qualities of the Aztec past and the personalities of historical figures. ${ }^{34}$ (Chavero, like Sierra, created connections between Aztec and Mexican nationalism.)

The cover of one edition of Chavero's text is decorated with Aztec images. The Aztec Calendar Stone occupies the center resting rests on the backs of two small sculptures of crouching gods. The base of the circular stone rests on the head of the fearsome Aztec earth goddess, Coatlicue. ${ }^{35}$ Her image was culled from the imposing stone sculpture in which her body and head are composed of serpents. Her face consists of two serpents heads that face one another. They form two eyes and one

\footnotetext{
${ }^{34}$ Alfredo Chavero, México A Traves de los Siglos: Historia Antigua y de la Conquista, vol. 1, nos. 1-2, (Mexico D.F.: Gustavo S. López and Justo Sierra), 1889. Mauricio Tenorio-Trillo, Mexico at the World's Fairs: Crafting a Modern Nation, (Berkeley: University of California Press, 1996), 70-1. Clio, 1993), 45.

${ }^{35}$ Enrique Krauze and Fausto Zeron-Medina, Porfirio: El Poder, (Mexico City: Editorial
} 
tongue like a human face. The top and bottom borders of the page are decorated with designs from the famous Tizoc stone and depict the Aztec King Tizoc taking prisoners. Sculpted at the height of the Aztec civilization the three pieces, Coatlicue, the calendar and the Tizoc Stone represent the finest examples of Aztec art. These images emphasized Chavero's belief that the Aztecs were the prime Indigenous group in Mexico.

Porfirian approval limited itself to ancient Indians not the living. The histories by Sierra and Chavero and the ceremonial activities of the President (to be discussed in Chapter IV) downplayed the importance of modern tribes. The pacification programs were meant to force indigenous groups to conform to the Porfirian economic future. The Aztec resistance had been extinguished 355 years prior. Their symbols could be utilized because their struggle with the Spanish (not the current Mexican administration) was in the past. The Aztecs, unlike the Yaqui and Maya people, were no longer a political threat.

Mexican and European audiences understood this approach toward identity. Though Europeans took pride in their modernity, scholars in this period were also interested in defining the roots of culture. They looked for this heritage in the antiquities of Greece and Egypt. When the Porfirians began to romanticize the Aztec past they met with resistance both domestically and internationally. In Mexico, the general opinion of Indians was that they were incapable of scientific thinking. Abroad, the popular view was that the Aztecs were fascinating but subhuman. The 
international public certainly did not believe that there had been a classical Aztec culture. 


\section{CHAPTER TWO \\ THE RAG OF BARBARISM:}

\section{AZTECS IN INTERNATIONAL THOUGHT}

Although Díaz condoned the use of Aztec images in national monuments and museums the Aztecs suffered from a terrible reputation. To create a successful symbol it was necessary for the Aztecs image to be sanitized because the international and even domestic popular perception was generally negative, thereby rendering the use of Aztec symbols futile.

\section{A. Lewis Henry Morgan}

The stage for the international reception of the Aztecs was set in the 1870's by two Americans, William H. Prescott and Lewis Henry Morgan. Prescott, a popular historian occasionally sacrificed the truth to exaggeration. The overall effect of his The History of the Conquest of Mexico, is that the Aztecs, although obvious barbarians, were a group with a firm social structure who had fought valiantly against the clever and violent Cortes. ${ }^{36}$

\footnotetext{
reprint 1964).
}

${ }^{36}$ William Hickling Prescott, The History of Mexico, (New York: Bantam Books, 1853, 
Prescott's view was considered romantic and was rebelled against by the anthropologist, Lewis Henry Morgan. Morgan gained a prestigious reputation after living among the Iroquois and examining their lives with anthropological methods. He was the first to employ this technique and fancied himself the "founder of Anthropology. ${ }^{37}$

Morgan believed that historians should read the conquistadors accounts of the conquest with a critical eye. He suggested that his contemporaries were enamored of the Spanish conquest. In Montezuma's Dinner: An Essay on the Tribal Society of North American Indian, Morgan said of Prescott and Hubert Bancroft, (the author of Native Races), "It [ancient society] caught the imagination and overcame Prescott, our most charming writer...and it carried up in a whirlwind [Bancroft] our author at the Golden Gate." 38

Morgan believed he disentangled the Aztec reality from the conquistadors exaggerations and distortions. However, his effort to reduce the grandeur of the Aztec image as it was explained by the Spaniard, Bernal Diaz, matched the archaeological evidence less than the soldier's accounts. Morgan believed that in their writings the Spanish imposed their own society's structure on Aztec society due to their lack of anthropological knowledge.

One example Morgan used to destroy the notion of the advanced Aztec civilization concerns the dwellings. He asserted that the Spaniards called

${ }^{37}$ Lewis Henry Morgan, Montezuma's Dinner: An Essay on the Tribal Society of North American Indians, (New York: Labor News Company, 1950), Title page.

${ }^{38}$ Morgan, 15. 
Moctezuma's home a palace simply because it was large. ${ }^{39}$ He thought the Spaniards presumed a monarch where none existed and that there was no need for a palace. ${ }^{40}$ Morgan, however, had never been to Mexico and did not mention viewing the drawings of ruins by Frederick Catherwood or Anthony Waldeck. ${ }^{41}$ It is possible that he did not know what these dwellings actually looked like. Without first hand knowledge he asserted that Aztec buildings were the same as the adobe homes found in Arizona and New Mexico. He assumed that the Aztecs had lived in Iroquois style long houses made of adobe. He guessed also that their social structure was similar to the Iroquois. Effectively, Morgan reduced the grandeur of the advanced Aztecs and Mayas and tried to reveal how vile he thought that they were. He believed that at the time of contact the Aztecs were savage, "They were still a breech-cloth people, wearing this rag of barbarism as the unmistakable evidence of their condition. Thus, the tone was set for the reception of Aztecs in the United States, as the "Iroquois of the South." ${ }^{43}$ In the 1880's few scholars argued against Morgan's pervasive viewpoint. $^{44}$

\footnotetext{
${ }^{39}$ Morgan, 17.

${ }^{40}$ Morgan argued Aztec social structure was similar to Iroquois society. No monarch existed among the Iroquois so Morgan did not expect to find one among the Aztecs.

${ }^{41}$ Catherwood's drawings of Maya ruins may be found in John Lloyd Stephens, Incidents of Travel in the Yucatan, vols. 1-2, (Mérida: Producción Editorial Dante). Nuttall included Waldeck's sketches in Zelia Nuttall, "Island of Sacrificios," American Anthropologist, vol. 12, (Sep 1910), 277 295.

${ }^{42}$ Morgan, 51.

${ }^{43}$ Benjamin Keen, The Aztec Image in Western Thought, (NJ: Rutgers University Press, 1971), 396. Due to their confederation of tribes the Iroquois were actually five tribes. This level of organization was considered by scholars to be an advancement for Indians. Thus, the Iroquois were considered the best political group among northern Indians. They were also considered to be the most violent due to religious and war practices that involved sacrifice. To be the "Iroquois of the South" means to be the "best of the worst," The most popular anthropologists who lived with the Iroquois are Morgan and Anthony Wallace. See Morgan, League of the HO-DE-NE-SAU-NEE or Iroquois, (New
} 


\section{B. Exhibitions}

At the turn of the nineteenth century scholars and politicians were not the only North Americans interested in determining what the image of the Mesoamerican could become. On a popular level, circus managers staging "freak shows" capitalized on the mysteries of Mesoamerica based on the North American public's curiosity and ignorance. In the United States, one of the side show's constant attractions between 1841 and 1930 was its exhibits of non-western people, including “Aztecs." Between 1841 and 1890 one popular brother and sister pair was Máximo and Bartola. They were exhibited as "The Last of the Ancient Aztecs," a fallacy as they hailed from lower Central America. ${ }^{45}$

Máximo and Bartola had been born with microcephaly. The educator and sociologist, Robert Bogdan, defined the condition, “Microcephaly is...a syndrome characterized by a small head with a sloping forehead: large, protruding ears and nose; unusually small stature...and moderate to severe subnormal intellectual functioning."46 The phrase "microcephalic" came into use during the eugenics

Haven: Human Relation Area Files, 1954), and Anthony Wallace, The Death and Rebirth of the Seneca, (New York: Knopf, 1970).

${ }^{44}$ Keen, 398.

${ }^{45}$ Robert Bogdan, Freak Show: Presenting Human Oddities for Amusement and Profit, (Chicago: University of Chicago Press, 1988), 127.

${ }^{46}$ Bogdan, 126. 
movement in science, when it was suspected that intelligence could be measured by the size of one's skull. ${ }^{47}$ It literally means small head.

Several circus people with microcephaly were advertised as ancestors of the Aztecs or from the Yucatan. Others were often advertised as Australian aborigines or Africans. Always the microcephalics were advertised as something foreign and exotic. The advertisers made little or no distinctions between Yaqui, Aztec and Mayan civilizations. Máximo and Bartola were dressed in clothing resembling the northern Mexicans. Their serape styles were adorned with mock Aztec designs. ${ }^{48}$ Beginning in the 1860's, the circus advertisers used the travel writings of John L. Stephens, a lawyer from New York who became an explorer, to excite curiosity about the exotic Maya and add validity to their stories. Only a poor showman neglected the opportunity to draw attention to the aesthetically sloped forehead of both the ancient Maya and the microcephalics. ${ }^{49}$

Máximo and Bartola were examined by physicians and various scientists in the United States and Europe. It was not until they arrived in England, in 853, that their status as the last Aztecs was challenged. ${ }^{50}$ Bogdan asserts that in medical literature the terms "Aztec-type" or "Aztec-like" became synonymous with

${ }^{47}$ William H. Tucker, The Science and Politics of Racial Research, (Urbana: University of Illinois Press, 1994). The vernacular phrase for people inflicted with this condition is "pinhead"; the term derived from the malformed heads that come to a point at the top.

${ }^{48}$ Bogdan, 128 and Drimmer, 128.

${ }^{49}$ Bogdan, 129. The ancient Maya bore sloped foreheads due to head binding. When showmen advertised "African microcephaly in the big show "Darkest Africa" (1930-1940), they attributed the sloped foreheads to head binding tribes in the jungles of Africa. Bogdan, 195.

${ }^{50}$ Bogdan, 130. 
microcephaly, thus indicating the influence the image exercised not only on the general public but even over the medical profession. ${ }^{51}$

There are other examples of microcephalics who experienced similar treatment in the show world. For these people, "The Aztec Girls," "Magie the Last of the Aztecs," "Pip and Flip from the Yucatan," "Rosi the Wild Girl of the Yucatan," the "Mexican Wild Boy," "Tik Tak the Aztec Pinhead," "Aurora \& Natali," "Máximo \& Bartola" and the countless others who were exhibited as "Aztecs" or "Mayas," the tragedy of their story is not so much that they were misrepresented, that happened to nearly every sideshow participant, but that they were individuals with no ability for self-determination and their dependency was exploitable. What it means for Aztec and Maya imagery is that not only were foreigners curious and ignorant about Aztecs and Mayas but that they were willing to believe stories that were exotic to extreme absurdities. The international public was willing to pretend or believe that "pinheads" and ancient Indians were of equal stature, below the common American. ${ }^{52}$

The North American public was genuinely curious. Oddities were popular in Mexico too. José Guadalupe Posada, sketched many people with deformities for newspapers in the capital. ${ }^{53}$ Aztecs were encountered before cameras and

\footnotetext{
${ }^{51}$ Bogdan, 145.

${ }^{52}$ Bogdan, 134, and Aztec Girls (San Francisco: Quality Postcard, 1992), Pip and Flip: Twins from the Yucatan with the World Side Show Circus, Coney Island (San Francisco: Quality Postcard, 1992), Bogdan explains that during the 1920's microcephaly came under the sympathy of medicine. After that time microcephalics in sideshows were often pitied.

${ }_{53}$ José Guadelupe Posada, Mexican Popular Prints, (Boston: Shambala Redstone Editions ,
} 1993), 26, 29 30-33, 36, 37. 
televisions, many had no idea what an Aztec would look like. The presentation of mentally and physically deformed people as Aztecs affirmed the notion that Indians were not as civilized as people of European heritage. It also dispelled any notion that Mexican Indians might have been superior to American Indians. Just as the inclusion of native north Americans in expositions and fairs emphasized their inability to evolve from their savagery and assimilate into the new culture of America.

The fraudulent side shows encouraged others to promote traveling art shows. By 1886, Benito Nichols and the Orrin Brothers, George and Edward, had gathered literary, military, archaeological and cultural artifacts from Mexico to be exhibited in the "Aztec Fair" in the United States. The fair's catalog claimed that many of the paintings and books were authentic although a few of the archaeological artifacts were reproductions. The major displays in the fair were mock villages with merchant and artisan shops populated by actual Mexicans.

The brochure discussed the sadness involved in recruiting the exhibit's members from their families in far off Mexico. The language in the guide leans toward the scientific but it is a thin veil.

Native Mexicans at the Aztec Fair. People from all parts of the vast republic have been enlisted, the principal difficulty being to get them to leave their sunny homes for a foreign country, as they are a people little given to travel, and exceedingly clannish in their customs....We have endeavored to secure those whose labors will be instructive and interesting to all. Visitors can see how these classes live and earn a livelihood, also their customs and how they amuse themselves. ${ }^{54}$

\footnotetext{
${ }^{54}$ Benito Nichols, Edward and George W. Orrin, Guide to Orrin Bro's and Nichols' Aztec Fair: Mexico Past and Present, (Orrin Bros. and Nichols, 1886), 5.
} 
Just as in circus freak shows humans were on display and Mexicans were an exotic curiosity to be delivered to the curious public of the United States.

The Aztec Fair was not the first or last example of Mexican Indians or peasants on display like curiosities in a zoo or side show. In 1895 and 1896 at the local fairs in Atlanta and Nashville, "Mexican Villages" were exhibited but relegated to the sections reserved for rare animals and side shows. This type of exhibit made it to the cosmopolitan stage in 1901 at the Buffalo World's Fair. Mexico erected a mock village titled, "Street of Mexico." Porfirio Díaz agreed to send authentic Indians to occupy the site on the condition that they would not be ridiculed.

However, Aztecs were not the only indigenous groups on display in the United States and Europe.

In the United States at the 1904 St. Louis world's fair Native Americans were exhibited in villages that were supposed to represent their original homes. The photo guide reveals the diversity of tribes attending the fair: Lakotas (Sioux), Apache, Pueblo and others. One photograph captured an Indian man (tribe not identified) dressed in western clothing, with loose hair and tattooed tear trails down his cheeks. His posture is erect and his expression is dignified. The caption, however, contradicts his stance by telling us of this man's return to barbarism. The title is CIVILIZED OR SAVAGE, WHICH? and the caption reads,

Here we have the product of a quarter of a century's contact with the white settler. This Indian had no sooner become settled in his new quarters at the 
fair than he forgot his civilized raiment, daubed on the war-paint and whooped with his fellows from the most remote reservations. ${ }^{55}$

Buffalo Bill's Wild West Show exemplifies the display of native cultures in the United States. The performances exhibited the conquest of the west as entertainment for the believers in Manifest Destiny. ${ }^{56}$ If American Indians were not getting respect in the United States, neither were Aztecs going to receive it.

\section{Sacrifice}

Internationally, the best known aspect of ancient Mexican cultures was probably that human sacrifice had been sacred to the Aztecs. Among male victims they often chose warriors, thereby incorporating foreign warriors and cultures into Aztec religion. This information concerning the Aztecs survived due to the preservation of books such as the Florentine Codex, which vividly portrayed Aztec human sacrifice. To the western mind, sacrifice was unacceptable. The Aztec practice of sacrifice did not equate to old testament biblical sacrifice in the minds of these observers. The Porfirians were challenged with the task of altering the sacrificial image of the Aztecs and turning it into one that reflected the goals of the Mexican government.

${ }^{55}$ The Complete Portfolio of Photographs of the World's Fair, St. Louis, 1904-- The Sights, Scenes and Wonders of the Fair Photographed: World's Progress Illustrated--A Grand Panoramic View of the Fair in all It's Glory--The Strange People of the World in Pictures, (Chicago: The Educational Company, 1904). (No page numbers are given but each photograph is titled, Civilized or Savage, Which?)

${ }^{56}$ For footage of the Wild West Show see Stephen Ives, The West, vol 7, (This is a documentary series), produced by Ken Burns and distributed by the Public Broadcasting System. 
Inherited from the colonial period was the perception of the native empires as "barbaric and bloody." This idea remained strong throughout the Porfiriato.

Coinciding with the administration's attempt to include Aztec icons into nationalist imagery were foreign scholarly debates that were incompatible with the whitening of the Aztec past. In his essay for the American Antiquarian Society, Philip Valentini, repeatedly reminded his readers that the Aztecs had originally dedicated their Calendar Stone with "bloody" rituals:

...of the bloody festival which was held for the dedication of this sacrificial slab...No doubt this stone served for all their bloody sacrifices up to the year 1521. Here follows a description of bloody combats...Again a bloody thanks giving...Then follows the description and upon it thousands of victims were slain...The king...drank of their blood. ${ }^{57}$

George MacCurdy, an anthropologist and chief curator at the Yale Museum also emphasized the "blood" associated with other artistically carved Aztec stones. In 1887, a Yale professor was able to purchase a valuable stone from the "Aztec Fair: Mexico Past and Present."58 MacCurdy determined that the purpose of this stone, now known as the Yale Calendar Stone, was that "victims destined to be sacrificed were fastened to by the arms or limb, a rope passing through the hole securing them." 59 He compared it to the Tizoc Stone (found in 1790) which supports similar carvings. To this day there exists a debate over whether the Tizoc stone was a sacrificial altar. The anthropologist Zelia Nuttall and the catalog to the Aztec Fair

\footnotetext{
${ }^{57}$ Philip J.J. Valentini, "The Mexican Calendar Stone," Proceedings of the American Antiquarian Society, (Worcester: Press of Charles Hamilton, 1879), 12. Emphasis mine.

${ }^{58}$ This piece may have been a replica of a stone in the Museum of Anthropology in Mexico City. The catalog to the fair does not have it listed as an original piece.

${ }^{59}$ George MacCurdy, "An Aztec 'Calendar Stone' in Yale University Museum," American Anthropologist, vol. 12, no. 4, (Oct-Dec 1910), 481.
} 
referred to the piece as the "sacrificial stone." similarities in the carvings on the two stones determined that he possessed a precious item, a sacrificial calendar stone. ${ }^{61}$

Complex and conflicting ideas circulated the globe concerning the Aztecs. The Spanish conquistadors spoke of an advanced civilization but by the late nineteenth century that reputation had dissolved. People forgot about the Aztec architecture, art and science and concentrated on the aspects of barbarity, such as human sacrifice. Curiosity left the international public vulnerable to fraudulent images of the Aztecs. Side shows and art fairs capitalized on the situation. This manipulation of the Aztec image made it necessary for the Porfirians to cleanse and redefine the Aztec past.

One method for controlling the images of the Aztecs was the control of archaeological sites in central Mexico. The Porfirian administration protected the sites connected to the Aztecs from foreign explorers. The national archaeologist arranged the artifacts from the sites in the national museum. These events did not often meet with the approval of foreign scholars whose access to the central sites was restricted. The next chapter will explore the way in which the Porfirian government contributed to the myth of Aztec superiority through the excavation of central sites and the neglect of southern and eastern sites.

\footnotetext{
${ }^{60}$ Zelia Nuttall, "Mexico," (1886), 100. Nuttall refers to the "Sacrificial Stone" that was being place in the National Museum at the same time as the Aztec Calendar, Stone. I believe that she is referring to the Tizoc Stone because it was commonly referred to as the "sacrificial stone" and because it was being placed at the same time as the Aztec Calendar Stone.

${ }^{61}$ MacCurdy, 490.
} 


\section{CHAPTER THREE \\ A PARADISE OF SPECULATORS: $:^{62}$ \\ LEOPOLDO BATRES \& ARCHAEOLOGY}

"The government is apathetic in regard to ruins and antiquities- till somebody finds something, then it is wide awake at once."

- Fredrick Ober ${ }^{63}$

Control over archaeological excavations also contributed to the shaping of indigenous images. It has been suggested that the developing interest in archaeology is what stimulated the use of indigenous images in the Porfiriato. ${ }^{64}$ Archaeological control enabled the government to stop archaeologists from stealing of artifacts. Most important, however, was that the national archaeologist also had the power to excavate any site deemed important and determine which items suited the national museum. Through the process of selection and censorship the Aztec image could be molded to fit the Porfirian ideal.

${ }^{62}$ Beals, 338. My section title references Beal's sentence, “A paradise of speculators," by which he meant Mexico under Porfirian administrators.

${ }^{63}$ Fredrick Ober, Travels in Mexico and Life Among the Mexicans, (Boston: Estes and Lauriat, 1884), 309.

${ }^{64}$ Rita Elder, "The Icons of Power and Popular Art," In Mexican Monuments: Strange Encounters, arranged by Helen Escobedo with photographs by Paolo Gori. (NY: Abbeville, 1989), 64. 
Through the development of the office of the Inspector of National Monuments, the Porfirians exercised greater control over Aztec sites than over Mayan. As the archaeological remains of the Maya were not located in the Valley of Mexico, the Porfirian government felt no need to instrumentalize Mayan images to obtain political legitimacy.

Excavations for the government were executed by the Inspector General and Conservator of the Archaeological Monuments of the Mexican Republic, Leopoldo Batres and his son Salvador, between 1884 and 1910. Knowing that Díaz held an interest in archaeology, Batres encouraged him to form the position of government inspector. Díaz relied on the recommendation of General Rocha, and Batres was instated in 1885 , two years after he had begun encouraging the federal government to fund digs at Teotihuacan. ${ }^{65}$ In his role as the national archaeologist, he began excavations in the Valley of Mexico and Oaxaca. Between 1885 and 1910 his publications were usually printed by the government, seemingly without limitations.

The creation of this post reveals the Mexican intention to include itself in the cosmopolitan intellectual community. Through Batres' work the government maintained control over archaeological sites in the Valley of Mexico, the historic center of power for the Spanish, the Aztecs and the Toltecs. Regarding the Mayan centers in the Yucatan, Batres' curiosity was limited while the areas in between

\footnotetext{
${ }^{65}$ Letter from Désiré Charney to Díaz, From Paris, 28 November 1887, catalog no. 012599. Letter from E. Boban to Porfirio Díaz, "Personal Communication" New York, 20 December 1886, catalog no. 0136681 . Letter of recommendation from Rocha, 21 May 1885. Catalog no. 004922 . All from the Archivo Porfirio Díaz de la Universidad IberoAmericana in Mexico City. Unpublished.
} 
Mexico City and Mérida attracted his attention but were not his priorities. The main sites to be discussed in this chapter are Teotihuacan, La Isla de Sacrificios, Chichén Itzá, and Mitla. These sites were the main areas of controversy during the Porfiriato.

\section{A. LEOPOLDO BATRES}

Batres' position made him an international figure in archaeology. Unlike more obscure archaeologists who did not contend with public criticism, as the first national Inspector and Archaeologist, Batres' work underwent severe scrutiny. His single qualification, enthusiasm, impressed no one and his constant mistakes and alleged pilfering of artifacts gave him the image of an old fashioned villain.

Batres entered a field controlled ideologically and physically by European and North American scholars. Europeans held archaeological footholds in Europe, Asia Minor, the South Western United States and Mesoamerica. ${ }^{66}$ In Mexico these foreigners were not all professionals but they were generally wealthy and educated. In the 1880's and 1890's archaeology was developing from a fashionable antiquarian pursuit of art to a professional search for the reasons behind the fall of civilizations. In particular, Prussian scholars led the way in excavations of ancient Greece, Rome

\footnotetext{
${ }^{66}$ See Suzanne L. Marchand, Down from Olympus: Archaeology and Philhellenism in Germany, 1750-1970, (Princeton: Princeton University Press, 1996), for information about German archaeologists; William Fairley, ed., Monumentum Ancyranum: The Deeds of Augustus, (Philadelphia: The Department of History at the University of Pennsylvania, 1898), 7, for information about French explorers; Charles H. Lange and Carroll L. Riley, Bandelier: The Life and Adventures of Adolf Bandelier, American Archaeologist and Scientist, (Salt Lake City: University of Utah Press, 1996), for information about the SW United States; Robert L. Brunhouse, In Search of the Maya, (Albuquerque: University of New Mexico Press, 1973) and Pursuit of the Maya: Some Archaeologists of Yesterday. (Albuquerque: University of New Mexico Press, 1975), for information on Mesoamerica.
} 
and the Middle East. They believed that by understanding the development of the ancient cultures they could better form German kulture, the notion of German high culture. Archaeologists were searching the pagan past for information about human cultural development. ${ }^{67}$ European archaeologists transferred these ideas and goals to Mesoamerica when they began excavations there. Their ideas about propriety clashed with Batres' character.

In contrast, Batres was not from the same social or economic class as most of the foreign scholars. He was born of the mistress of Manuel Romero Rubio, Díaz's minister of government, and his education was limited. ${ }^{68}$ Batres' favored position with Díaz stemmed from his brotherly relation with Díaz's second wife, Carmen. Batres had also served in the military under Diaz. ${ }^{69}$ He served as captain and was then expelled. ${ }^{70}$ His character seemed questionable to many foreign archaeologists.

Clearly, Batres did not fit into the clique of international archaeologists then active. He was not an intellectual, educated, rich or white. He was a creole, possibly a mestizo, and he was the last person foreigners expected to excavate the ancient American sights. Batres added a Mexican agenda to the field of archaeology. ${ }^{71}$ As a Porfirian administrator he was determined to prove that the indigenous people were not all degenerates and that the Toltec society equaled the ancient civilizations in

\footnotetext{
${ }^{67}$ In contrast, linguists were examining languages to understand Christian development. Marchand, Chapter Three.

${ }^{68}$ For information regarding Romero Rubio's political ideas see Hale, 107.

${ }^{69}$ Beals, 338.

${ }^{70}$ Boban, letter.

${ }^{71} \mathrm{He}$ had a personal agenda as well. This was not uncommon at this time and probably still is not.
} 
Europe and Egypt. ${ }^{72}$ Foreign scholars working in Mexico at this time were searching for answers to the decline of those civilizations. There was hope then that the New World would provide answers to the questions regarding the old world. Edward Thompson, a former consulate from the United States, for example, was attempting to prove that the Mexican Yucatan was Atlantis. ${ }^{73}$ These various goals in archaeology clashed during the years of Díaz's power and Batres position. Batres was never able to please the foreign archaeologists except when he allowed them access to any site they desired and did not question their excavation methods or conclusions. Bitterness arose among colleagues when the foreigners infringed on the sites in central Mexico where the Porfirians were excavating Nahua sites. The primary example of this is the city of Teotihuacan.

Ultimately the chapter suggests that the Porfirian archaeological policies mirror their larger political concerns. The field of archaeology provided the raw materials for symbols. The arrangement of these materials provided the image that the Porfirians wished to project domestically and internationally.

\section{B. BATRES AT TEOTIHUACAN}

\footnotetext{
${ }^{72}$ The American visitor, Alden Buell Case, believed that Mexican Indians had degenerated. "The Indians of various tribes, encountered here are a thoroughly subject and seemingly degenerate people, occupying the lowest stratum in the social make-up, servants, street-laborers, venders of toys and curios. It is interesting to learn, however, that Aztecs still dwell in this valley who have through all these years kept themselves more apart from the conquering race. These speak a language believed to be substantially that of their fathers. They are of more independent spirit and proud of their ancestry." Alden Buell Case, Thirty Years with the Mexicans, (New York: Fleming Revell Company, 1917), 93

${ }^{73}$ Edward Thompson, “Atlantis: Not a Myth,” Popular Science Quarterly, 51, (October 1879), 759-64.
} 
As an ancient Indian site of grandeur, the city of Teotihuacan, located slightly north of Mexico City, never had been overlooked. It was abandoned by its originators and by the time of Spanish arrival the Aztecs were using it as a religious space. They too abandoned it with the demise of their empire. In Batres' day the entire city seemed like an open field of rolling hills. In reality the hills were overgrown pyramids and palaces, but not forgotten and always inciting fondness. The American visitor, E.H. Blichfeldt remarked, “..passing the great prehistoric pyramids of the sun and moon at San Juan Teotihuacan, which I have seen many a time from car windows, and think of as old friends, though I never stop to visit them."74 Only two excavators had worked in this city prior to Batres' interest. However, it is likely that looters pillaged the site. ${ }^{75}$ This city became the most important site of Batres' career.

Batres spent the first ten years in his position as inspector examining Mayan, Zapotec and Mixtec sites. These remains had received attention from foreigners earlier, and many of them were located in the southern state of Oaxaca, the birthplace of Díaz. Batres' attention never focused seriously for any length of time until 1905, when he began the excavations that would keep him at Teotihuacan until 1910.

Although Batres began his examinations in Teotihuacan in 1883, it was not until 1905 that he secured the funding along with the order from Porfirio Díaz and Justo Sierra to excavate the Pyramid of the Sun in preparation for the 1910

${ }^{74}$ Blichfeldt, 108.

${ }^{75} \mathrm{~A}$ century of archaeologists have uncovered pyramids, palaces, walls, and shrines, many of which line up in a row commonly referred to as the "Street of the Dead." 
independence celebrations. Karl Tompkins, a writer of popular history, credits

Batres with the lead role in the initiation of the dig:

No sooner was Díaz inaugurated than Batres approached with the idea that if Teotihuacan were made into a great national monument it might add to Mexico's national image, and that if the Pyramid of the Sun could be unearthed and restored to its former shape in time to commemorate the centennial of Mexico's liberation from Spanish rule, due in September of 1910 , coincident with Díaz's birthday, it might cause enough of a splash to perpetuate the dictator in office. ${ }^{76}$

Tompkins did not give a source for this information but I speculate that

the idea of linking the excavation to a patriotic festival was probably Díaz's because his actions demonstrate a nationalist mind set whereas Batres' ideas were often self oriented.

The pyramids were considered symbols of nationalism as early as 1879 , when the nationalist painter, José María Velasco, presented his works, Pyramid of the Sun and Pyramids of Teotihuacan. These were commissioned by the director of the National Museum for his institution. Critics considered the pieces to be important because they represented two very important monuments of the neglected half of Mexican heritage. ${ }^{77}$ This viewpoint is all the more interesting because the site was not yet excavated and had barely been visited by the French explorer Désiré Charney. $^{78}$

\footnotetext{
${ }^{76}$ Peter Tompkins and Hugh Harleston, Jr. Mysteries of the Mexican Pyramids: Dimensional Analysis on Original Drawings, (New York: Harper \& Row, 1976), 192.

${ }^{n}$ Stacie Widdifield, The Embodiment of the National In Late Nineteenth Century Mexican Painting, (Tucson: The University of Arizona Press, 1996), 99.

${ }_{78}$ Ignacio Bernal, A History of Mexican Archaeology: The Vanished Civilization of Middle America, Translated by Ruth Malet, (Great Britain: Thames and Hudson, 1980), 149.
} 
Although the Mexican historian and archaeologist, Ignacio Bernal, credits Batres with securing funding for excavations, he stated a low opinion of Batres' work at Teotihuacan:

...this self-taught man explored these places with no knowledge whatever of digging techniques or serious study methods. There is more useful information in the modest excavation of [Désiré] Charney in Teotihuacan than in all the research Batres carried out in the immense city. ${ }^{79}$

Prior to Batres' work the only other substantial work had been done by Charney, who was also a friend of Díaz's and had toured sites with him in $1859 .^{80}$ Charney was a respected figure in Mexican archaeology because he was the first to notice structural similarities at the site of Tula, in the Valley of Mexico and at Chichén Itzá, in the Yucatan.

Placing aside the criticisms for a moment, it is interesting to examine the theories Batres developed concerning Teotihuacan. He argued that the Toltecs, the ancestors of the Aztecs, were civilized. It was in their history that modern Mexicans could take pride.

Batres believed that only two "races" had inhabited the city, the Toltecs and the Aztecs. ${ }^{81}$ The Aztecs assumed that they followed the Toltecs at the site and the

${ }^{79}$ Bernal, 149.

${ }^{80}$ Charney, letter no. 012599.

${ }^{81}$ The currently popular theory holds that there were at least three groups of inhabitants in succession. The most ancient group is referred to as the Teotihuacanos and their lives remain largely mysterious. [See Leo Duel, Conquistadors Without Swords: Archaeologists in the Americas, An Account With Original Narratives, (New York: St. Martin's Press, Inc., 1967), 187]. Modern archaeologists do not believe that the Toltecs ever inhabited Teotihuacan because the evidence suggests that the site was abandoned prior to the rise of the Toltecs. 
Spaniards followed that line of thinking, based on Aztec oral histories. ${ }^{82}$ Batres

believed that he had found architectural and crockery evidence to proving the link between the Toltecs and the Aztecs. He also cited the historical texts of the Spanish conquistadors as evidence of this. ${ }^{83}$

By comparing Toltec and Aztec artistic skills and sacrifice practices, Batres determined that the Toltecs were a more knowledgeable, peaceful and less primitive race than the Aztecs. When examining pottery remains found at Teotihuacan during his 1905-6 digs, Batres considered the Aztecs' skills to be inferior to those of the Toltecs'. "This pottery also differs completely from that of the Toltecs in form, color and quality. It is less artistic, almost primitive....or rather degenerated"84 Without training that would enable him to make distinctions between the two artistic styles, Batres based his decision on textures, colors, designs and certainly personal preference.

Clearly Batres believed that the Toltecs did not engage in the practice of human sacrifice. In his discussion of the "sacrificial stone" discovered at Teotihuacan, Batres emphasized his idea that the stone bore an inappropriate name for a Toltec piece.

\footnotetext{
${ }^{82}$ Stephen Aaberg and Joy Bonsignore, "A Consideration of Time and Labor Expenditure in the Construction Process at the Teotihuacan Pyramid of the Sun and Poverty Point Mound," Three Papers on MesoAmerican Archaeology: Contributions of the University of California Archaeological Research Facility, (Berkeley: University of California, 1975, No. 24), 41.

${ }^{83}$ Batres, Teotihuacan $O$ La Ciudad Sagrada de los Toltecas, bilingual edition, translator Unknown, (Mexico: Talleras de la escuela N. de Artes y oficio Ex-Convento de S. Lorenze, 1886), 1618; and "Las ruinas Xochicalco," Congreso Internacional de Americanistas XVII, (Mexico: Museo N. de Arqueologia Historia y Etnolgia 1910), 4.

${ }^{84}$ Batres, Teotihuacan O La Ciudad, 17-18.
} 
This very inappropriate name was born of a phantasy preoccupied with the traditions of human sacrifices among the Aztecs; since it is known that the Toltecs never made human sacrifices nor offered the entrails of their fellow beings to their gods. On the contrary the offerings which they bore to their temple were the products of the earth, as for ex: flowers, seeds, fruits, occasionally birds..." 85

Batres emphasized and valued the myth of the peaceful intelligence of the Toltecs.

Through his work at Teotihuacan he tried to symbolically draw the Mexican government and the capital closer to Teotihuacan. However, his thinking was not entirely original as Charney had previously endorsed many of the same ideas. ${ }^{86}$

Although Batres exhibited a preference for the "civilization" of the Toltecs over the "barbarism" of the Aztecs, he did not shun the latter as ancestors. That would not have been in keeping with the process of raising the Aztec image during the Porfirian administration. Nor would it have allowed him to persuade Díaz to fund excavations for Aztec sites. Additionally, if the Monument to Cuauhtémoc was valuable for his symbolic fight against the Spaniards, the Aztec fighting power could be showcased. Batres' polarized vision of Toltecs and Aztecs allowed him to think of the Aztecs as the strength of Mexico and the Toltecs as the civilization. What this means ideologically is that the Aztecs were the link to the past but Batres preferred the Toltec culture which extended the line of legitimization. For him, legitimization

\footnotetext{
${ }^{85}$ Batres, Teotihuacan O La Ciudad, 16, (There did exist at this time one other stone that was referred to as the "sacrificial stone." It is now known as the Tizoc stone and had been found in the Zocálo and inducted (October 1879) into the Museum of anthropology in 1886), Nuttall, "Mexico," 100.

${ }^{86}$ Bernal, 126.
} 
lay with the "superior" Toltecs with whom the Mexicans should associate. Mexicans had to be civilized like the Toltecs, but they also had to be strong like the Aztecs.

\section{TEOTIHUACAN: CRITICISMS}

The Pyramid of the Sun became the national symbol of Mexico by design. It appears that Mexico City supported Batres' work and ideas concerning Teotihuacan because several administrators participated in the inauguration of the Pyramid of the Sun. In September, 1910 Batres arranged for several archaeologists to visit the site as part of the Congreso Internacional de Americanistas conference and the independence celebrations. This trip included many influential scholars and politicians such as: President Díaz, the Minister of Public Instruction and the Fine Arts; Justo Sierra, a government archaeologist and author; Alfredo Chavero, ${ }^{87}$ the German anthropologist; Edward Seler, the anthropologist; Frans Boas, the Swedish paleontologist; Ales Hrdlicka, the English amateur archaeologist; Alfred Tozzer, the Mexican scholar; Nicolas Leon, the American Consul; Edward Thompson, the cosmopolitan professor; Zelia Nuttall, and of course, Batres. Batres probably expected that he would receive praise for his excavation from the members of this trip. Indeed, he did get public support from Díaz and Hrdlicka, but they endorsed

\footnotetext{
${ }^{87}$ Chavero often disputed Batres' interpretations concerning artifacts. See Batres' discussions of the Coatlinchan stone that now adorns the drive way to the National Anthropology Museum in Mexico City. Batres, El Sr. Lic. Alfredo Chavero Y El Monolito de Coatlinchan, (Mexico: Fidencio S. Soria, 1904), and Batres, Contestación a la Dúplica del Sr. Lic. Alfredo Chavero: En la Controversia de Monolito de Coatlinchan, Series: Documentos para la Historia de Mexico, vol. 11, (Mexico: Fidencio S. Soria, 1905).
} 
Batres' work for political reasons. Nearly every other scholar condemned Batres' methods of excavation.

Batres became notorious for his excavations at Teotihuacan. During the five years of work he felt rushed. In his hurry he had the workers strip the outer mural of the Pyramid of the Sun and alter its original structure. Very likely, the murals would have required removal and placement in a museum for protection from environmental factors, but the murals removed by Batres disappeared. Drawings of the murals before they were destroyed depict them as detailed plants and offerings to the gods. ${ }^{88}$ Batres altered the temple by "giving it five intermediary platforms instead of the archaeological correct four." ${ }^{\text {}}$ Scholars may only guess at the original structural dimensions because it is believed that Batres did not record his excavation procedure, despite keeping a daily journal and the plethora of materials he published regarding Teotihuacan. ${ }^{90}$

Batres' contemporaries held low opinions of his decision to remove the murals. The independently wealthy British amateur Mayanist Alfred P. Maudslay was appalled by the stripping of the temple. He declared that Batres' careless removal of the Pyramid of the Sun's outer layer was "a stupendous amount of self assertion and incompetence." 91 Today the naked Pyramid of the Sun bears stones up its sides that might have supported the heavy murals. Additionally, Batres was

\footnotetext{
${ }^{88}$ Eduardo Matos Moctezuma, Teotihuacan, (New York: Rizzoli International Publication Inc., 1990), 28.

${ }^{89}$ Aaberg and Bonsignore, 41-2.

${ }^{90}$ Meyer, 128-130.

${ }^{91}$ Brunhouse, Pursuit, 44.
} 
accused of selling artifacts for his profit. ${ }^{92}$ The murals disappeared, and some suspect that he sold many artifacts through his antique store, possibly even the murals. Carleton Beals, the biographer of Díaz, wrote scathing comments regarding Batres, whom he termed an "adornment":

A wholesale and retail merchant in antiquities, he rifled the nation of its archaeological treasures, blew up an Uxmal arch to steal a statue, robbed the treasures of Mitla....He also grafted illegal permits to take art objects out of the country. The public joked: "Señor Batres, excavating in the pyramids, has already gotten out two automobiles."

In 1906, however, Batres defended his work at Teotihuacan. Batres argued that removing the murals was a requirement for revealing "la verdadera forma," or the true shape of the temple. ${ }^{94} \mathrm{He}$ asserted that the temple had been cut to match the angle of the staircase that ran up each level of the pyramid. Questioned as to why he felt the need to cut the pyramid and not just uncover it, Batres responded that he cleaned the pyramid by making it neat and pure. Furthermore, he claimed that his goal was to determine the method by which the pyramid builders constructed it. He thought it necessary to dismantle part of it in order to determine the date of construction. $^{95}$

At the Congress of Americanists in 1912, Batres shifted the blame for the ruined murals to the Minister of Public Instruction and the Fine Arts, Justo Sierra. He wrote that the order to excavate came from Sierra's secretary too late in 1905 and

\footnotetext{
${ }^{92}$ Nuttall, "Island," note 1, 282.

${ }^{93}$ Beals, 338.

${ }^{94}$ Batres, Teotihuacan: Memoria, (Mexico: Fidencio Soria, 1906), 12.

${ }^{95}$ Leopoldo Batres, "Descubrimientos y consolidación de los monumentos arqueológicos de Teotihuacan," Congreso Internacional de Americanistas, 1912, 188-193.
} 
that the department gave too little time or money. The largest problem that he faced was the task of removing large amounts of dirt with wheelbarrows each day. $\mathrm{He}$ hired villagers to cart away a maximum of one hundred tons per day. ${ }^{96}$

To emphasis the importance of his work, Batres measured the Pyramid of the Sun and pronounced it superior to the Egyptian pyramid, Cheops, because the Pyramid of the Sun was ninety meters wider at the base. ${ }^{97}$ Batres tried not only to equate the Toltecs to the splendor of the ancient Egyptians culture but he also tried to surpass it.

In his brief discussion about the Teotihuacano murals Batres did not specify whether he found them inside or outside the structures. His lack of discussion subtly devalued the murals. ${ }^{98}$ Díaz received suggestions that he remove Batres from his post from the time that the latter attended an archaeological conference in Paris in 1885. Díaz not only maintained Batres as the inspector but also condoned his excavation of the pyramid. After Díaz and his administrator, Justo Sierra, visited Teotihuacan in 1906, Díaz purchased the pyramid and stated: ${ }^{99}$

The Inspector General of Archaeological Monuments follows the methodical exploration in the monuments of San Juan Teotihuacan, having already achieved the total discovery of one of the sides of the great Pyramid of the Sun. He has begun discovering three other various and neighboring

\footnotetext{
${ }^{96}$ Tompkins, 193.
}

${ }^{91}$ Batres, Teotihuacan: Memoria. 21. This is an example of his ignorance since he either did not know the level of sophistication involved in building the steeper pyramid of Cheops or he ignored it.

${ }^{98}$ Batres, Teotihuacan: Memoria. 28.

${ }^{99}$ Vuelo: Mexican, Ejemplar coleccionable de cortesia, (Mexico: Medio Publicitario Impresos, January 1996), 62. 
constructions, in which he had been able to see that numerous and important frescoes are visible. ${ }^{100}$

In this passage, Díaz plainly stated that Batres followed a method intended to be scientific and not destructive. Furthermore, he tried to pacify the opposition by directing attention toward the several remaining murals.

Eventually Batres destroyed those murals also. The only remains of them were his drawings. Edward Seler questioned the validity of those sketches at the Congress of Americanists of 1912. ${ }^{101}$ Batres, then exiled in Spain, responded that Seler's criticism was too harsh. He said that Seler could easily be critical of Batres because he worked under less pressure.

In 1910, the paleontologist, Ales Hdrlicka defended Batres because the inspector had afforded him access to tombs at Teotihuacan. ${ }^{102}$ Hrdlicka used Batres' friendship to gain access to burial sites at Teotihuacan in his life long quest to prove inferior qualities of New World people. ${ }^{103}$ Perhaps Batres later regretted his association with Hrdlicka when the latter published an article propounding the superiority of white children over African American children. As a paleontologist, Hrdlicka concerned himself with the progression of humankind. Eventually his conclusions, drawn from examination of Mexican Indian remains, would not provide

\footnotetext{
${ }^{100}$ Enrique Krauze and Fausto Zeron-Medina, El Derrumbe: Porfirio, (Mexico: Editorial Clio, 1993), 51. This passage was translated by myself with assistance from Aaron Arguedas.

${ }^{101}$ Edward Seler, "Similarity of Design of some Teotihuacan Frescoes and Certain Mexican Pottery Objects," Congreso Internacional de Americanistas, (1912), 199.

${ }^{102}$ Ales Hrdlicka, "Differences between White and Colored Kids," American Anthropologist, 1909, 347-57; and Douglas Preston, "Fossils and the Folsom Cowboy," Natural History. vol. 106, no 1, (Feb. 1997), 16-22.

${ }^{103}$ Hrdlicka, Congreso Internacional de Americanistas, 1910, minutes, 47.
} 
a beneficial international image for the Porfirians. In 1925, Hrdlicka notoriously dominated the academic discussion regarding human settlements in the Americas. He did not believe that evidence existed for settlements older than $1000 \mathrm{BC}$. Any attempt to prove earlier habitation suffered scathing scrutiny from Hrdlicka while he was the curator of the Smithsonian's Division of Physical Anthropology. By 1927 Professors. Frank Figgens and Carl Schwacheim discovered strong evidence that people had arrived in New Mexico at least 10,000 years earlier, but Hrdlicka would not acknowledge it. ${ }^{104}$

Modern writers credit Batres with having persuaded the president to give government support to several archaeological projects. Batres' work at Teotihuacan damaged the site, but he began the national archaeology program that survives to this day. ${ }^{105}$ Additionally these future scientists of Mexico began receiving scientific training in 1910 at the newly established school of anthropology. Díaz lent his support to this new school. ${ }^{106}$

Indeed, Batres' excavation was hurried due to pressure to prepare for the independence celebration of 1910. Díaz specifically ordered this site to be exhumed in 1905. Aztec mythology deemed Tula the city of the gods, whereas Teotihuacan was considered the birthplace of the gods. ${ }^{107}$ Díaz was deliberately attaching himself

${ }^{104}$ Preston, 16-22.

${ }^{105}$ Bernal, 149.

${ }^{106}$ Tenorio-Trillo, 93.

${ }^{107}$ Kathleen Berrin, "Reconstructing Crumbling Walls: A Curator's History of the Wagner Murals Collection," Feathered Serpents and Flowering Trees: Reconstructing the Murals of Teotihuacan, edited by Kathleen Berrin. (Hong Kong: The Fine Arts Museums of San Francisco, 1988), 26-30. 
to Aztec myth by demanding the excavation of Teotihuacan. This connection was made more intimate when he purchased the Temple of the Sun for himself. ${ }^{108}$ Batres' lack of skill came close to damaging the efforts to establish a symbolic lineage. Possibly, the overwhelming criticisms put a strain on his good relations with the president.

As the scrutiny on Mexico increased just prior to the independence celebrations so did the focus on Leopoldo Batres. After all, he intended that his work showcase the glory of the ancient past for the celebrations. However, the attentions toward Batres' activities provided fewer benefits for Díaz. One woman in particular, the intelligent and boisterous Zelia Nuttall, directed her attention toward discrediting Batres.

\section{LA ISLA DE SACRIFICIOS: BATRES AND NUTTALL}

Widowed and financially independent, Zelia Nuttall lived in the United States, Paris and Mexico City. ${ }^{109}$ Toward the end of Díaz's administration she added her voice to the barrage against Batres. In 1909, Nuttall, then the Honorary Professor of the Mexican National Museum and Honorary Assistant in Mexican Archaeology at the Peabody Museum of Harvard University (and later a professor at the University of California), struggled to undermine Batres' authority. ${ }^{110}$

${ }^{108}$ Vuelo, 62.

${ }^{109}$ Tompkins, 207 and Batres, La Isla de Sacrificios: La Señora Zelia Nuttall de Piñard y Leopoldo Batres, (Mexico: Tipografia Economica, 1910), 4.

${ }^{110}$ Nuttall's qualifications are given in her article, "Island," 280 , and in the minutes to the 1910 Congreso Internacional de Americanistas, 37. 
Near Vera Cruz, on the Isla de Sacrificios she discovered and excavated, in view of many witnesses, three meters of an ancient structural wall. The architecture she found resembled that in the Mayan regions of the Yucatan. Additionally, she uncovered art work nearly identical to the Aztec Calendar Stone and frescoes of the god, Queztalcoatl. Because her find was vulnerable to the sea, she photographed it and then had Mexican workers build a small levy. Upon her return to the mainland she traveled to Mexico City to:

ask permission to continue my researches on the island, offering, in return, my time and services gratis, with my written pledge that all objects that I might find would be faithfully and unconditionally delivered to the government official appointed to receive them."

It was rare for foreign archaeologists to request permission. Nuttall herself had excavated her yard in Mexico City without asking permission. ${ }^{112}$

Her colleagues forewarned her that the inspector, Leopoldo Batres abused his position as the national archaeologist and that he would hinder her project. None the less, Nuttall requested and secured permission to excavate the site along with a grant of 500 pesos for supplies. After a delay of three weeks Nuttall was sent a letter that decreed that she would be given only 200 pesos. Secondly, her work must be limited to a certain unspecified part of the island. Third, citizen Salvador Batres, the assistant to the Inspector of Archaeological Monuments, would supervise her work. Lastly, "explorations for which permission has been granted her, are to be carried

${ }^{111}$ Nuttall, "Island," 277.

${ }^{112}$ Zelia Nuttall, "Aztecs and Predecessors in the Valley of Mexico," En Miscelanea, (1926). 245-255. 
out, in every detail, according to the laws, regulations and dispositions of the subject." ${ }^{113}$ Nuttall attempted to clarify those rules and was delayed further with the result that the inspector went to the island and claimed the discovery of the ruins as his work. His announcement was posted in the government newspaper, $E l$

\section{Imparcial.}

Nuttall further stated that Batres had rearranged artifacts in the National Museum and reorganized them during his brief stay as director there. He placed items from the Isla de Sacrificios along with pottery from Teotihuacan and labeled all the items as artifacts from Teotihuacan. She provided sketch drawings published prior to the Batres system and photographs after it that clearly demonstrated his reorganization. Nuttall declared that Batres' system was inaccurate and spoiled the classification completed by the German archaeologist and anthropologist Edward Seler over the previous two years. ${ }^{114}$ Nuttall claimed that when she addressed Batres personally, he denied her allegations:

At the entrance door I met Señor Leopoldo Batres, to whom the Minister of Public Instruction [Justo Sierra] had recently handed over the entire reclassification of the Archaeological Department of the Museum, which meant the undoing of the task for which Prof. Edward Seler had been called to Mexico. On mentioning to Señor Batres the object of my visit to the museum he astonished me by stating, categorically, that "there was nothing from Sacrificios in the whole museum."115

\footnotetext{
${ }^{113}$ Nuttall, "Island," 279.

${ }^{114}$ Nuttall, "Island," 284.

${ }^{115}$ Nuttall, "Island," 282-4.
} 
However, Nuttall did find items from the island and proved Batres' system was fraudulent. Additionally, the proprietors of the Aztec Fair, a traveling mercantile show in the United States claimed to be selling items from La Isla de Sacrificios. Clearly, objects from the island were obtainable. ${ }^{116}$

In the June 1910 volume of The American Anthropologist, Nuttall published her version of this dispute. Batres managed to publish a defense prior to the conference in September. This dialogue died after Batres went into exile with Díaz. Manuel Gamio, a student of Nuttall's replaced him. ${ }^{117}$ Batres stated that not only was his professional reputation damaged by Nuttall's accusation but that he felt betrayed by her. He responded slowly because Nuttall, despite her fluency in Spanish, had published her article in English, a language he did not read. This delayed his access and response to her allegations and he viewed the act as a little sneaky. ${ }^{118}$ Batres' defense, La Isla de Sacrificios: La Señora Zelia Nuttall de Piñard y Leopoldo Batres, questioned Nuttall's right to devalue his authority. He challenged her qualifications although she had more anthropological and archaeological experience in Mexico than he did and the titles she held impressive titles just as he did.

Batres referred to the Director of the National Museum of Anthropology, Genaro García and the Minister of Public Education, Justo Sierra, for validation. This was clever, for if García did not mind a reclassification then why should anyone

\footnotetext{
${ }^{116}$ Nichols and Orrin, 7-15.

${ }^{117}$ Tompkins, 207.

${ }^{118}$ Batres, La Isla, 3-4.
} 
else? Batres claimed that García chose him to replace the "nonconformist" Edward Seler. $^{119}$

Additionally, the support of Justo Sierra would have been valuable because he was the Minister of Public Instruction, an intellectual of the Porfirian administration, a supporter of projects dealing with indigenous people and he seconded García's choice to employ Batres for the reorganization. ${ }^{120}$ Nuttall spoke bitterly of Sierra's support for Batres' projects. ${ }^{121}$ Sierra had even taken Batres on a tour of archaeological sites in the Yucatan. ${ }^{122}$

As for the German anthropologist and archaeologist, Edward Seler, generally regarded by scholars as an expert, he published no response to Nuttall's claim that Batres was ruining his classification pattern. ${ }^{123}$ During the conference, Congreso Internacional de Americanistas, 1910, he lodged a formal complaint against Batres and reiterated his objection at the 1912 congress. ${ }^{124}$ The nature of the dispute remained confined to the main committee (of which Batres was a member) and did not make it into the official record. ${ }^{125}$ Without knowledge of the nature of Seler's objection it is difficult to choose a side in this debate. Batres defended his position

${ }^{119}$ Batres, La Isla, 7.

${ }^{120}$ Hale, 8, Nuttall, "Island," 283; and Batres, Isla, 7.

${ }^{121}$ Nuttall, "Island," 280. A view seconded by Alfred Maudslay, a critic of Batres' work at Teotihuacan but disputed by the Ales Hrdlicka. Indeed, the professional relationship between the two men was close.

${ }^{122}$ Batres, Datos Arqueológico, (Barcelona, 1911), 1-3.

${ }^{123}$ Perhaps he did not join the dialogue because he was not overly fond of either Nuttall or Batres. In 1893 he had published a harsh critique of Nuttall's ideas regarding Aztec feather working. See Eduardo Seler, "Ancient Mexican Feather Ornaments," in Mexican and Central American Antiquities, Calendar Systems and History, 1893, translated by Charles P. Bowditch, (Washington: Government Printing Office, 1904), 59-74.

${ }^{124}$ Congreso Internacional de Americanistas, 1912, minutes, 47.

${ }^{125}$ Congreso Internacional de Americanistas, 1910, minutes, 46. 
and his country. Nuttall defended the emerging ideals of professional archaeology and anthropology. ${ }^{126}$

Batres did not address the newspaper article that announced his having claimed the site at the island. Instead he gave Nuttall credit for uncovering that particular area but devalued her findings because he believed they were not native to the site and only that quality would make the artifacts significant. He believed that the artifacts traveled to the temple with pilgrims, a viewpoint Nuttall did not dispute. 127

Batres defended his reclassification by responding that he had organized the artifacts by style and culture rather than by which site they derived from. ${ }^{128}$ Batres' logic allowed him to place items from Teotihuacan, Mitla and Isla de Sacrificios, together under the site heading of Teotihuacan because he believed those places bore the mark of Toltec influence. Batres thought that the Toltecs originated at Teotihuacan, therefore all items influenced by the Toltecs went under that label. If Batres was sincere, then the system may have seemed logical to him. Sincere or not, the newly labeled objects added to the prestige of Teotihuacan as an archaeological site. This would then enhance Batres' reputation and improve the images of the

\footnotetext{
${ }^{126}$ The atmosphere at the Congreso Internacional de Americanistas might have been tense for at least three reasons. First, the conference was held the second week in September 1910, a time of political hostility in Mexico. Secondly, Batres response to Nuttall's attack was published just prior to the conference and it had the potential for polarizing the participants. Thirdly, Nuttall's presence was somewhat unexpected because she had retired from the conference committee. On the first day of the gathering she managed to be appointed as the representative from the University of California, (Congreso, 37). The Mexican Revolution probably interfered with the published dialogue between Batres and Nuttall.

${ }^{127}$ Batres, Isla, 5; and "El Cascabel de la Culebra Mitologica de Teotihuacan," Boletin de la Sociedad de Geografia, 1890.

${ }^{128}$ Batres, Isla, 5-6, and Nuttall, "Island," 238.
} 
Toltecs and Aztecs. Through his position as the National Archaeologist Batres controlled the presentation of unfavorable or preferred images.

\section{E. MITLA}

Mitla represents a geographic mid-way point between Teotihuacan and the site of Chichén Itzá in the Yucatan. Batres paid attention to this site because it is in Oaxaca, Díaz's native region. However, he did not deem it a politically important site and was careless in his treatment of it. He was accused of sending his servants to pilfer the tombs.

In June 1910, a local paper, El Tiempo, charged Batres with not fulfilling his title of Conservator of Monuments. Batres received notification concerning an open tomb at the site of Mitla in Oaxaca. Rather than sending the archaeologist Alfredo Chavero or his son to inspect the area he sent his untrained domestic servant. $E l$ Tiempo insisted that the examinations should be conducted scientifically in order to avoid a loss of data:

Measurement of distances and depths, should be taken, the material found should be separated and examined, photographs should be taken-in fact, everything should be done in order to discover what science is always hungry to learn....In the present case this is not only a question of scientific interest, but one which involves Mexico's good name. We therefore hope that with all activity and energy steps will be taken to avoid the ridicule that threatens us and the loss of the data which may be obtainable from said discovery. ${ }^{129}$

${ }^{129}$ Nuttall, "Island," 281. Translated from the Spanish by Nuttall. She cites, El Tiempo, 2 June, 1910. She considered the newspaper to be respectable, conservative, patriotic and Catholic. 
This editorial passage reveals three things. First it is clear from the commentary that there existed an established intellectual dislike for the ineptness of Batres' methods. Secondly, there was a respect for the developing scientific research methods Third, Batres' behavior was seen as a violation of nationalism, and El Tiempo wanted him removed if only for that infraction. If Batres could not be removed from office because he was incompetent in archaeological matters, then perhaps he could be removed because he damaged the national image. His carelessness was giving Mexico an international reputation for sloppiness. His abuse of artifacts undermined the attempt to manipulate artifacts to promote nationalism. This effort by the government was obvious to the newspaper editor who felt that it was Batres' duty to protect artifacts which could potentially represent nationalism. When Batres allowed damage to occur at Mitla it seems that he betrayed his country.

\section{E. CHICHÉN ITZÁ}

Between 1860 and 1910, foreign archaeologists enjoyed access to the Mayan sites in the east (unless they were prohibited by the Maya living in the vicinity, which happened often.) During the Porfiriato, the Yucatan Maya resented the Mexican government's involvement in the Caste War so strongly that some Maya entertained the idea, proposed by British archaeologists, that they join the British nation against the Mexicans. ${ }^{130}$

${ }^{130}$ Paul Sullivan, Unfinished Conversations: Mayas and Foreigners Between Two Wars, (New York: Knopf, 1989), 138-140. In the 1860's Mexican politicians viewed this idea as an infringement on their country and as a serious threat. Arnold Blumberg, "The Diplomacy of the 
The government paid little attention to the deeds done by archaeologists or vandals in the Mayan temple unless local officials made formal complaints. Mayan sites were not then protected by the government. The Austrian archaeologist Teobert Maler asked in frustration:

Did the Mexican government...permit [just] anyone to attack the temples and palaces of a glorious past, tumbling down parts that struck their fancy, piercing every thick wall in search of mummies, implements, and treasure which did not exist? Did it allow those reckless adventurers to make molds which pulled stucco and stones from the walls, or wrench off finely carved pieces to take out of the country. ${ }^{131}$

The intellectuals of Mexico did have expectations of Batres. The criticism of his behavior at Mitla reveals that a criteria for professional archaeological behavior was developing. Batres carelessness at Mitla was apparently not his first breech of the nationalist ideal. In the previous year, Sierra and Batres visited the site of the sacred cenote, a sunken well, at Chichén Itzá. ${ }^{132}$ Lindsay Jones, described the importance of this cenote:

For the traditional Maya, the Sacred Cenote is home to the chacs, the temperamental gods of rain: it is for them a mouth, a womb, an opening out and an entrance into the subterranean netherworld of dark water, ultimately tapped to the sea, it is a point of sacred access at which their petitions have the best chance of being heard at which their debts can be expediently settled. ${ }^{133}$

\footnotetext{
Mexican Empire, 1863-67," Transactions of the American Philosophical Society held at Philadelphia for Promoting Useful Knowledge, New Series, Vol. 61, Part 8, 74.

${ }^{131}$ Brunhouse, Pursuit, 17.

${ }^{132}$ This sacred cenote was the cause of much controversy in the sixteenth century and is mentioned by Fray Diego De Landa. For more information see De Landa's writing, Relacion de las Cosas de Yucatan: A Translation. Translated by A.M. Tozzer, (Cambridge: Peabody Museum, 1941),

${ }^{133}$ Lindsay Jones, Twin City Tales: A Hermeneutical Reassessment of Tula and Chichén Itzá, photographs by Lawrence G. Desmond, (Niwot, Colorado: University Press of Colorado, 1995), 2.
} 
Accordingly, young women were thrown into this well communicate with the gods. Those who survived the fall gave divine advice. Those who did not live provided the sacrifice for appeasement. ${ }^{134}$

The American amateur archaeologist, Edward Thompson, the legal owner, dredged the cenote for signs of human sacrifice at the time of the visit. A former US consul, Thompson, worked for himself but gained his validation from his association with the Chicago Museum of National History and the Peabody Museum in Boston. Thompson had not requested formal permission for the project and was also shipped his finds to the Peabody Museum. ${ }^{135}$ These activities violated the Mexican policy which required permission, prior to retention of pieces and restoration of artifacts.

Thompson's singular objective was to prove that Diego de Landa had written the truth in the sixteenth century when he described the sacrifices offered to the well. Thompson tells us, "I was diving in the Sacred Well of Chichén Itzá to prove that this venerable water pit was once used for human sacrifice."136 Although in a time when it was believed that the Maya had been exceptionally peaceful civilization, Thompson never explained his desire to prove that they too performed human

${ }^{134}$ Jones, 32.

${ }^{135}$ Brunhouse, Search, 41.

${ }^{136}$ Edward H. Thompson, The People of the Serpent: Life and Adventure Among the Mayas, (Boston: The Riverside Press Cambridge, 1932), 4. Thompson did not provide much insight as to his preference to dredge the cenote even though Chichén Itzá is a city rich with several ancient buildings such as, El Castillo, a pyramid structured around solstice patterns, the Temple of Warriors, the Temple of Jaguars, the Palace of the Nuns and an astrological observatory, (For a map of Chichén Itzá see Mundo Maya, [Editions Nouveaux-Loisirs, 1995], 204-205), Thompson acknowledged those structures but limited his excavations to searching the cenote, uncovering a high priest's grave, deciphering the date stone which he found, and traveling to other sites.

Thompson's devotion to excavating the well was life threatening as the diving was an arduous and dangerous process in which he was required to wear a full under water suit connected to a hose through which Mayan workers pumped air, (Thompson, People, 281.) 
sacrifice. This aim is inconsistent with his earlier goal to prove that the Yucatan was the lost island of Atlantis. Like most visitors he started with an assumption and tried to mold the reality of Mexico to the myth. Thompson was not criticized by Batres for his morbid search through the well but he did suffer the disapproval of the revolutionary Mexican government. He was scolded for sending artifacts from the cenote to the United States. He probably did not think there was anything wrong with this practice. He viewed himself as a scientist not as an amateur. ${ }^{137} \mathrm{He}$ thought his project was legitimate because it continued the work begun by Désiré Charney in $1882 .^{138}$

Additionally, it was normal for foreigners to have ownership rights in Mexico. Between 1894 and 1909 foreigners were able to purchase "public land" and Thompson acquired the Chichén Itzá site from a ladino family in $1903 .{ }^{139}$ This included a run down home which he intended to use as a botany lab, all the ruins and some land. The sacred cenote was part of that land. Thompson hoped that the plantation aspect of the hacienda would provide enough money to make his work independent of the American museums and to pay for the Indian workers. ${ }^{140}$ It was also not entirely unknown for an individual, even a foreigner, to own a temple and site. In 1839, the famous American traveler, John L. Stephens had purchased the

\footnotetext{
${ }^{137}$ Thompson, People, 11.
}

${ }^{138}$ Clemency Chase Coggins and Orrin C. Shane III. ed. Cenote of Sacrifice: Maya Treasures from the Sacred Well at Chichén Itzá, (Austin: University of Texas Press, 1984), 24.

${ }^{139}$ John Barrett and Francisco J. Yanes (Director and Assistant Director), "Land Law (1894)," Mexico: A General Sketch, (Compiled by the Pan American Union: Washington DC, 1911), 352.

${ }^{140}$ Thompson, People, 232. 
Mayan site of Copan, Guatemala. ${ }^{141}$ Instances of ownership of this magnitude demonstrate that Mexico at the turn of the century allowed foreigners to own important historical sites and that the Mexican government was not deeply concerned with sites far from the seat of government.

Thompson may have felt that his ownership of the land entitled him to dig and to send the artifacts to the United States. Many Mayanists did not secure permission to pursue excavations just as the German amateur archaeologist, Heinrich Schliermann, neglected to obtain the necessary excavation permit before beginning the dig at Troy in $1870 .{ }^{142}$ Perhaps Thompson shared sentiments with Fredrick Ober, a traveler who believed that foreigners had the right to remove any artifacts they desired. As Ober expressed it:

An antiquarian is not like the wise man, who found a treasure and went straight away and hid it; but he, immediately he discovers anything of value, sets up such a howl of self-glorification that the attention of the whole world is directed thereto. Then while the excavator is absent, looking for some means of conveying his treasure out of the country the government steps in and quietly carries it off. Thus Mexico is enriched. ${ }^{143}$

Clearly, Ober believed that a scholar's right to inquiry and removal surpassed a nation's right of possession. He did not assume that Mexico might use those artifacts for national identification but instead that it was normal for foreigners to be able to take what they wished even if there was a law in Mexico that forbade the removal of artifacts.

${ }^{141}$ Eduardo Galeano, Memory of Fire: Faces and Masks, Vol. II. Translated by Cedric Belfrage, (New York: Pantheon Books, 1987), 151.

${ }^{142}$ Caroline Alexander, “Troy's Prodigious Ruin," Natural History, April 1997, 46.

${ }^{143}$ Ober, 309. Italics mine. 
Even if Thompson did not share Ober's presumption he may have been unaware of the Mexican law regarding antiquities or confused by Mexican mining law because it had been twice altered after 1884 . The antiquities law was proposed in 1875 by a congressman from Oaxaca who was concerned about the amount of artifacts leaving the country. ${ }^{144}$ It extended an earlier law from 1825 that was aimed at decreasing the amount of antiquities sold abroad. ${ }^{145}$

This law was tested in December of that year, 1875. At Chichén Itzá the flamboyant French amateur archaeologist, Augustus Le Plongeon, came upon a stone reclining figure bearing an offering plate. This style of figure is referred to as a chac mol. ${ }^{146}$ Le Plongeon intended to exhibit the chac mol at the centennial celebrations in Philadelphia but the local curator in Mérida alerted the officials from Mexico City about his scheme. ${ }^{147}$ Le Plongeon hid the carving in the bushes in Piste but it was secured by officials from the capital who arrived on a war ship. ${ }^{148}$ The Mexican president, Tejada, refused to return the piece to Le Plongeon and interdicted its exportation to the United States. ${ }^{149}$ Despite this dramatic example, the antiquities law was seldom enforced. For example, it did not prevent the Metropolitan Museum of Art in the United States from purchasing in 1900 a basalt stone carving of the

\footnotetext{
${ }^{144}$ Charles H. Lange and Carroll L. Riley. Bandelier: The Life and Adventures of Adolf Bandelier, American Archaeologist and Scientist, (Salt Lake: University of Utah Press, 1996), 62. ${ }^{145}$ Keen, 397.

${ }^{146}$ The currently popular theory is that sacrificial hearts were placed into the plate among several Mesoamerican cultures.

${ }^{147}$ At the Philadelphia fair Mexico was exhibiting a neoclassical building with Aztec adornments, (Tenorio-Trillo, 39.)

${ }^{148}$ Brunhouse, $133-4$.

${ }^{149}$ Today it is exhibited in the National Institute of Anthropology in Mexico City.
} 
Aztec Water Goddess, Chalchiuhtlicue, dated to the late fifteenth or early sixteenth century. ${ }^{150}$ The example of Le Plongeon and the Mayan Chac Mol demonstrates that the Mexican government was willing to enforce the antiquities law when an was item of interest. However, Batres did not choose to use the law against Thompson.

There another alternative existed if Batres wished to persecute Thompson's infraction. The mining code established in 1892 and reaffirmed in 1909 stipulated that any gold or silver found beneath the land's top soil were "owned by the Federal government, representing the nation wherever they may be found, whether in private ground or in the public domain." 151 If Batres and Sierra chose not to persecute Thompson under the rarely used antiquities law, then they may have absorbed his activities under the mining code, but they did not.

Neither Sierra nor Batres pressed the violation into legal matters.

Thompson's biographer, Robert L. Brunhouse, attributed Batres' failure to prosecute Thompson as Díaz's unofficial policy. "Because both officials were charged with preservation of the nation's antiquities, their failure to take action can be attributed only to the indulgent attitude of the Díaz regime toward foreigners in Mexico."152 Nuttall's struggle with the Porfirian administration (although she placed no blame on Díaz, only on Batres) discounts Brunhouse's too simple explanation. As this was a violation of governmental policy, then I speculate that Batres saw no personal gain in

\footnotetext{
${ }^{150}$ John B. O'Neill, The Metropolitan Museum of Art: The Pacific Islands, Africa and the Americas, (New York: Branford D. Kellher, 1987), 130.

${ }^{151}$ Barrett and Yanes, "Mining Code of Mexico," Mexico, 362.

${ }^{152}$ Brunhouse, Search, 187.
} 
pursuing a prosecution. Perhaps he did not realize that a few of the artifacts were made of gold and silver. On an ideological level Batres' actions may have been leading Tenenbaum's argument that the Porfirian administration felt obligated to usurp legitimacy from the Aztecs and not the Mayas. Under these circumstances Batres may not have thought that the Mayan artifacts contributed to the nationalist mythology. Especially not in the Yucatan where the Caste War continued off and on until 1910. Additionally, the Maya in the vicinity resented the Mexican government due to the official support given to the ladinos during the battles. ${ }^{153}$

There was yet another reason why Batres did not condemn Thompson's actions. He did not think that Chichén Itzá was a valuable site. Batres published an article in which he compared pillars at Teotihuacan and Chichén Itzá. The respected theory established by Désiré Charney had been that pillars at Tula, a Toltec site in the Valley of Mexico and pillars at Chichén Itzá were similar, therefore, the Toltecs influenced Chichén Itzá. ${ }^{154}$ Batres believed that he discredited this theory when he proposed that the "Toltec" pillars at Teotihuacan were much taller and superior than those at Chichén Itzá. Additionally, he believed the columns had served different purposes. The columns at Chichén Itzá were meant to support the sky while those at Tula were meant to support some type of ceiling or arch. With this argument Batres determined that Chichén Itzá was not of Toltec origin and was therefore a less

${ }^{153}$ Additionally, charges against a former US consul may have been viewed as an affront to the United States. Batres was not in a position to make such charges without the president's permission. However, when Thompson was charged with theft of the national treasure, after the revolution, the US government did not involve itself.

${ }^{154}$ Jones, chapter 1-2. 
important site than Teotihuacan. Because he believed Chichén Itzá was not of Toltec origin, hence beyond the influence of the superior Toltecs and their followers the Aztecs, he was not interested in the site archaeologically or politically. ${ }^{155}$

However, Batres' lack of action against Thompson would leave the situation open for future problems. ${ }^{156}$ After the revolution Thompson publicly announced that he had sent artifacts to the United States. His action gave meaning to the removal of the artifacts. They became symbols for the Mexican government's lack of control in the Yucatan and over foreigners. The lack of control over foreigners represented the incompleteness of the Porfirian nation. ${ }^{157}$

Through the office of the Inspector of National Monuments, the Porfirians created the position through which they could acquire raw materials, artifacts and

${ }^{155}$ Batres, “Cascabel," 199-201.

${ }^{156}$ Shortly after the revolution Thompson angered his Meridian tenants who then burned a good portion of his hacienda, including his priceless collection of Mayan artifacts and library. Perhaps he was disillusioned, because in 1923 he publicly announced in the New York Times, that he had excavated the cenote and sent the finding to the United States, all of which he knew was in violation of Mexican policy. The revolutionary government "represented his smuggling as theft of a great national treasure," (Brunhouse, Search, 187).

Thompson's hacienda was taxed heavily and the Mexican government demanded that the Peabody Museum return the gold and silver artifacts In 1959 the Peabody made an exchange with the National Museum of Anthropology in Mexico City where some of the artifacts are now on display in the Maya room, (The year is noted in Chase and Coggins and Orrin, 25), Regarding the amount of gold and silver in the items from the well, Thompson later remarked that the value was exaggerated and amounted only to a total of sixteen pounds, (Brunhouse, Search, 191, 193).

${ }^{157}$ After the Mexican Revolution the Mayan sites were given serious consideration by the government. When the American Sylvanus Morley began excavations at Chichen Itzá for the Carnegie Institute in 1924 he worked under the stipulation that he would not remove or ask the Mexican government for artifacts and that he would restore the structures. Morley volunteered to follow Mexican law and thus his proposal was favored over those other initiations that regularly requested artifacts, (Brunhouse, Pursuit, 67.) These rules applied to Morley were part of the antiquities law passed in 1875, but prior to the 1910 revolution it was enforced randomly, (Brunhouse, Pursuit, 67.) It could also be subverted if one carried enough cash for local officials and shippers in Mérida, (Brunhouse, Search, 138, 140). 
ruins, and determine the alterations and presentations of those objects. Batres enjoyed the privilege of preserving, neglecting or destroying ruins. He determined the categories for artifacts. These opportunities were given with the notion of improving the image of Indians from central Mexico. However, these activities were discovered and not appreciated by international scholars who did not benefit.

The attempt to mask Batres' lack of skill as an archaeologist manifested itself in the form of Centennial Celebrations in 1910. The next chapter will discuss the dedications and the monuments at the center of the celebrations. Through these activities the Porfirians paid homage to their European and Indian heritage. At the same time they maintained control of the images that they used. 


\section{CHAPTER FOUR}

\section{THE INVASION OF STATUES: ${ }^{158}$}

\section{NATIONALISM AND PUBLIC ART}

"We nowhere in the Spanish colonies meet with a national monument erected by the public gratitude to the glory of Christopher Columbus and Hernan Cortes."

-Alexander Von Humboldt ${ }^{159}$

\section{A. EUROPE}

Mexican heritage was descended from Old World Europeans and New World Indians. Díaz took advantage of this by symbolically linking his legitimacy in both directions. To understand the uniqueness and motivation of the manipulation of Aztec images we must look first to his society and its cultural, political, and intellectual connections with Europe. This chapter will examine the government's use of public art as a venue for promoting Mexico's European and Aztec heritage.

${ }^{158}$ My title comes from Carlos Monsivais' statement regarding Porfirio Díaz, "Throughout his dictatorship he was to unleash the invasion of statues, at that time irrefutable evidence of the advent of the nation's maturity," Carlos Monsivais, "On Civic Monuments and Their Spectators," in Mexican Monuments: Strange Encounters, arranged by Helen Escobedo with photographs by Paolo Gori, (NY: Abbeville, 1989), 105-128.

${ }^{159}$ Ober, 350. 
That Mexico never severed its cultural ties to Europe even after the French intervention is not unusual. Three hundred years of colonial rule left a deep European impression on the people of New Spain. They were descendants from Europe and its landscape. All the political and religious gathering places were of western design. During the Porfiriato political and cultural ties to European countries other than Spain, were given attention. France and Prussia were particularly popular. ${ }^{160}$

Díaz was aware that Prussia influenced France's withdrawal from Mexico. Additionally, he respected Bismarck's ability to unify the various Germanic peoples. Porfirio Díaz, modeled some small aspects of his government on the Prussian example. Besides the French, the Prussians held appeal for Díaz because in their military he could see a unifying force. Díaz had attempted the same type of forced unification by employing the military to conquer rebellious sectors in the Yucatan and in the North. Another obvious example is that military uniforms were purchased from the Germans. ${ }^{161}$ Díaz himself donned the characteristic pointed helmet known as the picklehaube. Additionally, a portrait of the Kaiser hung next to Díaz's presidential chair in the Castle of Chapultepec. ${ }^{162}$ In 1912 he went to Prussia and was honored with a review of the troops. Díaz's contemporary and loyal biographer,

\footnotetext{
${ }^{160}$ This was true of all of Spanish and Portuguese America after independence. For information regarding South America see Fredrick M. Nunn, The Time of the Generals: Latin American Professional Militarism in World Perspective, (Lincoln: University of Nebraska Press, 1992), 4.

${ }^{161}$ Blichfeldt, 113.

${ }^{162}$ For a photograph of the Kaiser's portrait see Anita Brenner, The Wind that Swept Mexico: The History of the Mexican Revolution, 1910-1942: Historical Photos, assembled by George R. Leighton. Series: Texas- Pan American (Austin: University of Texas Press, 1971), 114-115.
} 
Carleton Beals, commented, "In the grandness of Prussia he saw the image of his proper intentions for grandeur."163

The Mexican Revolution sent Díaz into exile in May 1911. In exile, Díaz became a man of European style. His first visit was to Paris and then to Prussia. In 1913, he journeyed to what was perhaps the most mysterious and famous archaeological grouping of the world, the pyramids in Egypt. That Díaz would tour this site is not surprising. Díaz was a supporter of archaeology prior to his presidency. He had even taken a tour of sites in Mexico with the French explorer Désiré Charney in $1859 .{ }^{164}$ Throughout his presidency he supported various excavations and promoted the start of a national archaeological school. Furthermore, a visit to the pyramids was quintessential for the upper classes traveling abroad.

In the ten years prior to his exile, Díaz supported the construction and dedication of European style public monuments in Mexico city. In January of 1902, the Pan-American conference was held in Mexico City. To commence the gathering and begin work on the long awaited Monument to the Wars of Independence, Díaz himself laid the first stone. The statue would become known as El Angel de la

${ }^{163}$ Enrique Krauze and Fausto Zeron-Medina, Porfirio: El Destierro, (Mexico: Editorial Clio, 1993), 39. Translation by myself. However, German weaponry did not appeal to the Mexican military. The equipment demonstrated by the German ambassador was faulty. It has also been suggested that the German representative did not understand the importance of the system of bribery. Ironically, the military weapons were purchased from the French. [Friedrich Katz, The Secret War in Mexico: Europe, the United States, and the Mexican Revolution, (Chicago: University of Chicago Press, 1981), 59-60.] The rivalry was forgiven when Mexico and France recognized each other again one year after Díaz gained office, in 1887.

${ }^{164}$ Charney, letter no. 012599. 
Independencia (The Angel of Independence). ${ }^{165}$ The keynote speaker, Ramon de Ibarrola, spoke admiringly of Díaz,

[The cornerstone] is about to be laid by the hand that was strong in battle and magnanimous in victory, by the hand of the citizen whose great practical sense taught him to lead his people away from barren, nay fratricidal strife and to direct its energies into the useful avenues of public works.... ${ }^{166}$

The construction of the statue was a ten year process but was finally unveiled, by

Díaz, on 16 September 1910 , the exact date of independence. ${ }^{167}$

This statue, the highest and the most glorious on the Paseo de la Reforma, a showcase street, is Mexican in content but European in style. First, the monument is uplifted by an enormous base of stairs. On the four corners of the base are obelisks. The are symbols of ancient Egypt and culture. They are also symbols of dominance because Napoleon I had stolen an obelisk from Egypt. ${ }^{168}$ Around the bottom level of the monument prowl two lions, symbols of courage. ${ }^{169}$ Above them are carved the names of heroes of the independence movement. On the second level are statues of Roman women who represent Peace, Law, Justice and War. Above them are four leaders of the independence movement including the famous Mexican priest Miguel Hildalgo, an icon of the movement for independence, who is waving the Mexican

${ }^{165}$ Tenenbaum, 145.

${ }^{166}$ Tenenbaum, 146.

${ }^{167}$ Tenenbaum, 147.

${ }^{168}$ These obelisks could be there due to Masonic influence. Masons often used the obelisk as ymbol of ancient culture, for example, the Washington Monument in Washington DC. Also, Díaz $s$ a Mason and in the same year dedicated a statue to America's most famous member, George Washington. Monsivais, 118.

${ }^{169}$ The use of lions may also reference the use of lions at ancient Greek sites such as Mycenae. H.W. Janson, History of Art, 4th edition, revised by Anthony F. Janson, (New York: Harry Abrams, Inc., 1991), 148. 
flag. Behind Hildalgo a tall straight column soars into the sky, upon which is perched an angel with large open wings. She wears only a billowing toga sheet slipping off her hips and revealing her full bare breasts. ${ }^{170}$ She carries a broken chain in her lowered left hand and a laurel crown in her raised right hand. The broken chain represents the break with Spain but the laurel represents a link with classical Greece. In the Greek tradition laurel leaves represented immortality. ${ }^{171}$ A laurel crown is a fitting award for a nation celebrating its independence from its mother country, and for Díaz, a man who at this time had been president of Mexico for nearly thirty-four years.

The laurel crown was again used in a monument to former president Benito Juárez. El Hemiciclo, Al Bienmierto, Benito Juárez, La Patria (The Half circle, to the National Hero Benito Juárez, the Fatherland) was inaugurated by Porfirio Díaz in 1910 also as part of the independence celebrations. ${ }^{172}$ This monument is wholly European in style. It is a half circle of Greek Doric columns. In the middle of the circle, at the base crouch two courageous lions. In the triangle of figures that top the monument are Juárez, seated before an angel slightly to his right and Lady Liberty with her torch slightly to his left. Juárez is wearing his customary suit with a Greek style robe over his left shoulder. The Angel is frozen in the motion of crowning Juárez with a laurel crown, a reference to the divine crowning of Greek

${ }^{170}$ Like the French lady of Liberty, Marianne.

${ }^{171}$ Robert Graves, The White Goddess: A Historical Grammar of Poetic Myth, (New York: Farrar, Strauss and Giroux, 1980), 391.

${ }^{172}$ Charles A. Weeks, The Juárez Myth of Mexico, (Alabama: University of Alabama Press, 1987), 72. 
rulers. The American visitor E.H. Blichfeldt felt shocked and overwhelmed by the size of the statue and particularly by the artist's audacity to crown Juárez with a gold plated laurel wreath.

I was happy enough to know this lovely park when one could pass along it without being startled, amazed, and shocked by the colossal statue of Juárez which now fronts Avenida Juárez at about the middle point of the southern edge. Colossal as is the statue, one feels what must be the instant effect when a great wreath, not of marble but of gold, is clapped down upon its head by one of the like wise colossal angels....One fancies that some enemy of Juárez must have had to do with this hideous perpetration. If the gold leaf could be all removed, the total effect would be less than half as bad. ${ }^{173}$

For the Porfirians this monument linked their administration to classical Greece but also to Juárez, who by the efforts of politicians was becoming a national hero. Two other examples of construction linked the Porfiriato to Europe and reaffirmed Mexico City as the international and domestic seat of power in Mexico. First, Mexico's participation in world's fairs and second, the construction of an opera house. That Mexico participated in world's fairs reveals that the government desired to be a part of the cosmopolitan community. The structures they created were designed to show Europe and the United States that Mexico was not culturally inferior. These projects were also intended to instill confidence into the domestic atmosphere. The historian Mauricio Tenorio-Trillo commented, "Many Mexicans

${ }^{173}$ Blichfeldt, 140 . The park he refers to is the common gathering place known as the Alameda. Blichfeldt was unimpressed with the statue but it is clear from his memoir that he disliked a great deal of Mexican art and might have approved of the same piece if it were of European origin. [Janet De Saules, Getting to Know Spain and Spanish, (Great Britain: Times Four Publishing Ltd, 1993), 10. This simple tourist guide for children contains a drawing of the semicircle monument in Retiro Park in Madrid, Spain built by King Philip II. The Semicircle to Juárez was possibly modeled after this one]. 
viewed participation in world's fairs as one of the best ways of changing the widespread perception that Mexico was violent and uncivilized." 174 Many of the pavilions used Aztec images through architecture and sculpture. Thereby, the sanitized and re-invented of the Aztec image was intended to save the Mexican Republic and impress the modern world.

The construction of the opera house, El Palacio de Bellas Artes (The Palace of Fine Arts), also provided an international link from Mexico to Europe because all important cities had a theater. It was a symbol of high culture. Most of the acts that would perform in the theater would be European or from the United States. The visitor Blichfeldt commented,

The eight-million-dollar theater at the east end of the Alameda is a thing to challenge admiration at once...One cannot help wondering by what use will be made of so fine a theater when it is finished, seeing that Mexico has no drama worthy of the name....Good opera, indeed, especially Italian opera, is already heard and appreciated. I heard Tetrazzini in Mexico before she had ever sung in New York. However, every Latin American capital must have its costly national theater, so why cavil as to what is to be done with it? It is a conventional ornament. ${ }^{175}$

The theater was never fully constructed until after the end of the revolution. ${ }^{176}$ Blichfeldt formed his observations of Mexico in his visits between 1909-11, and he did not see the finished product.

Today, the palace is the epitome of Mexican neoclassical architecture with a few indigenous elements. Greek and Roman forms adorn the facade, hide in the

\footnotetext{
${ }^{174}$ Tenorio-Trillo, 38.

${ }^{175}$ Blichfeldt, 138-9. Emphasis mine.

${ }^{176}$ Brenner, 158-9.
} 
balconies and stand at the foot of the building. This is best exemplified by the Aphrodite/Venus form emerging from her shell at the very center of the facade. ${ }^{177}$ Aztec warrior masks now adorn the entryways. The mixture of European and Aztec classical sculpture makes the theater Mexican while the images remain pure because they are separate from one another. ${ }^{178}$

Although world's fairs and public art works reminded Mexico of its European heritage some of those works provided fodder for nationalist sentiment through the manipulation of indigenous images.

\section{B. Aztecs}

\section{Monuments}

To the Porfirian administrator and historian, Justo Sierra, Cuauhtémoc, the high priest and last of the Aztec kings, was not only the “...soul and genius of the resistance..." ${ }^{179}$ against the Spaniards in 1521 but he was also the "...noblest epic figure in American history." 180 It is not surprising then in 1895, for the price of five centavos one could purchase a postal stamp bearing the king's image. A different stamp with the king was not issued again until 1910 for the independence celebrations. Significantly, these stamps of Cuauhtémoc were the only ones issued

\footnotetext{
${ }^{177}$ At the foot stands the Greek lady of law who is also represented on the base of The Angel of Independence and the painting, The Allegory of the Constitution.

${ }^{178}$ The irony that permeates the opera house these days is that the interior of the upper floors is dedicated to displaying the works of the revolutionary artists who have become institutionalized by their inclusion into this museum. Such artists include Diego Rivera, Jose Clemente Orozoco, Rudulfo Tamayo and David Alfredo Siquieros.

${ }^{179}$ Sierra, 60.

${ }^{180}$ Sierra, 62.
} 
of an indigenous person prior to the Mexican revolution. The stamps bear the image of the Monument to Cuauhtémoc ${ }^{181}$ dedicated on the Paseo de la Reforma in 1886 by Porfirio Díaz in a grand ceremony. These stamps emphasized the social value placed on the monument. Cuauhtémoc and Benito Juárez became iconographic figures in Porfirian public art. Monuments to these men were meant to mold them into Porfirian symbols of the nation. These images originated in Mexico City but were also planted in Paris and Oaxaca.

Barbara Tenenbaum theorizes that the statue of Cuauhtémoc represents the Porfirian claim to legitimacy:

The statue also telescoped the Porfirian intention to assert that the rulers of Tenochtitlan henceforth would represent the entire Mexican nation...Through this identification not just with the Indian as opposed to the Spanish past but specifically with the Aztecs per se, the Porfirians...position themselves as heirs to their predecessor's imperial legacy...The official historians...intended to use the monument to Cuauhtémoc and the official veneration of the Aztecs to reconfirm the power of Mexico City and its right to rule the nation by inheritance.

The Porfirians had fiscal goals in mind as well. By insisting on Cuauhtémoc as their first ancestor, they asserted their rights over state revenues as the Aztecs had once taken tribute...The statue thus delivered the symbolic coup de grace to political and fiscal federalism and proclaimed the primacy of the central state as embodied in and ruled by Mexico City. It served notice that the Porfirians planned to include centralism in their definition of liberalism. ${ }^{182}$

The Porfirians obtained legitimacy by association with the Aztecs in the same way that the Aztecs had acquired legitimacy by association with the ancient Toltecs.

\footnotetext{
${ }^{181}$ Scott 1995 Standard Postage Stamp Catalogue, 151 Edition Vol. 4: European Countries and Colonies, Independent Nations of Africa, Asia, Latin America, J-Q, (Sidney, Ohio: Scott Publishing Co., 1994), 350-55.

${ }^{182}$ Tenenbaum 141.
} 
In both cases the previous history was manipulated to have meaning approved of by the latter group. The Aztecs altered Toltec history to obscure their lack of presence in the Valley of Mexico prior to Aztec domination. ${ }^{183}$ They made the abandoned city, Teotihuacan into a "city of the gods" and (mythical) descent from the Toltecs became politically sacred. ${ }^{184}$ In essence, the Aztecs manipulated the Toltec image for their benefit. The Porfirians also attempted to alter the perception of their predecessors to highlight the image they wished themselves and foreigners to have of Mexico. In order to claim the Aztecs as political ancestors the Porfirians had to alter Aztec history to suit their purposes.

The melding of European and Indian images can be seen in the person of Cuauhtémoc. His facial features are of classical European design. The final sculptor on the project, Miguel Noreña, had been trained by the Mexican neoclassicist Manuel Vilar. ${ }^{185}$ It was natural for Noreña to sculpt in that fashion but the result is a statue that only slightly resembles indigenous people. The head supports a Roman style helmet with a plume of feathers extending from the forehead to the base of the neck. The feathers do add an indigenous element but a European style helmet was not uncommon in Porfirian Mexico. The military and Díaz, himself donned Prussian helmets. Cuauhtémoc's robe is Greek-like and the designs taken from the codices

${ }^{183}$ Inga Clendinnen, Aztecs: An Interpretation, (NY: Cambridge University Press, 1991), 10.

${ }^{184}$ Matos, 11.

${ }^{185}$ Justino Fernández, El Arte del Siglo XIX en el Museo, (Mexico: Universidad Nacional Autónoma, 1952), 117. 
add an indigenous element. His clothing marks him as civilized and this honors him as a European-like leader more than as an indigenous one.

The Monument to Cuauhtémoc embodies the most "positive" aspects of Mesoamerican culture. The base of the statue is worthy of attention. First, it is a tiered base, nearly a pyramid upon which Cuauhtémoc stands at military alert, ready to thrust his spear. The upper tier is covered with snakes, a reference to the time when Aztecs were forced to live off the meat of serpents. ${ }^{186}$ Many of the elements of the statue are of Aztec design or reference pre conquest leaders. The sides of the second tier are decorated with Aztec war shields and eagle and jaguar warrior costumes. On the north side the Aztec war shield bears the emblem of the Eagle and the Serpent. This derives from the Aztec foundation myth that the wandering Mexican tribe knew they had found their promised land when they spotted an eagle perched on a cactus with a serpent clasped in its talons or beak. The emblem also brings the element of Mexican nationalism to the statue because the image had been adopted for the national flag in 1821.

The bottom of the second tier is inscribed with the names of pre-Hispanic leaders from the Valley of Mexico. The name Cuitlahuac, on the north side, refers to the intermediate Aztec monarch, after Moctezuma II and prior to Cuauhtémoc. He is remembered for the Aztec military success on el noche triste (the sad night) when the

186The serpent bares many symbolic meanings, such as fertility and immortality. These meanings probably do not apply here except through a connection with masculinity. Masculinity is a fitting symbol for a warrior. See Graves, 125. 
Aztecs successfully drove the Spaniards out of their city Tenochtitlan. ${ }^{187}$ Cacama, on the west side, refers to the King of Acolhuacon, martyred in 1519. Finally, the name, Coanacoch on the east side refers to the king of Texcoco who was killed by Cortes when he marched to Honduras in $1525 .{ }^{188}$ All total, these three names symbolize the triumvirate of cities that united against other cities in the valley of Mexico and beyond prior to Cortes' arrival. In having chosen these names the Porfirians emphasized their belief that people indigenous to the Valley of Mexico were of a more civilized strain than coastal people because they were better organized politically. Additionally, the Porfirians would have viewed the existence of a union (between the cities) as a sign of a higher culture. Popular beliefs may have mingled also, because some thought the Acolhuas and Aztecs descended from the Toltecs. ${ }^{189}$ In the Spanish American mind these were the best elements of the Indian civilization.

The bottom tier of the monument is engraved with Roman classical style reliefs. The engraving on the east side depicts Moctezuma greeting Cortes and his men. On the west side Cortes observes as Cuauhtémoc is tortured by the Spanish as they tried to force him to surrender his mythical stash of gold. This subject matter was later reproduced in the 1892 painting, The Torture of Cuauhtémoc, by Leandro Izaguirre. ${ }^{190}$ Again, the focus is on the strength and anguish expressed by

\footnotetext{
${ }^{187}$ Tenorio-Trillo, 108. A separate monument to Cuitlahuac currently exists two statues farther on the Paseo, built in the twentieth century.

${ }^{188}$ John Bierhorst, Nahuatl-English Dictionary and Concordance to the Cantares Mexicanos, (Stanford: Stanford University Press, 1985), 88.

${ }^{189}$ Blichfeldt, 16.

${ }^{190}$ Widdifield, 117.
} 
Cuauhtémoc while his feet are burned. The content is Mexican history but the medium is European. Cuauhtémoc seems like a nobleman in contrast to Cortes who oversees the torture.

Finally, the architectural skill of the ancient cultures was incorporated into the base of the monument that was sculpted with designs from Mayan, Mixtec and Zapotec sites. ${ }^{191}$ (At this time the National Inspector of Monuments and Archaeology was interested in these sites.) The American visitor E.H. Blichfeldt remarked that the Mixtecs and Zapotecs were remembered for having fought against Cortes. ${ }^{192}$ These sites are located either in southern or eastern Mexico, far from the capitol. In physical form Cuauhtémoc, the symbol, stands on top of the other Mesoamerican cultures. The Aztecs had never incorporated all of Mesoamerica into their empire but the monument accomplished this for them symbolically. Additionally, by including groups that the Aztecs never conquered the Porfirians were projecting their desire to extend the nation into Yaqui and Mayan territory. Adding complexity to Tenenbaum's theory that the Porfirians used Aztec symbols for political legitimization, is the observation by Fredrick Ober, recorded in his Travels in Mexico in 1884. While visiting the Paseo de la Reforma, Ober noted that the foundations had been laid for six glorietas. The Mexican intellectual, Justino Fernández, tells us that two of the areas chosen were reserved for statues of the priest, Miguel Hildalgo and Benito Juárez. ${ }^{193}$ However, Ober commented on a

\footnotetext{
191 Tenenbaum, 140.

${ }^{192}$ E.H. Blichfeldt, A Mexican Journey, (Chautauqua, NY: Chautauqua Press, 1919), 51-52.

${ }^{193}$ Fernández, 167 and Tenenbaum, 135.
} 
different plan to erect monuments to both Cuauhtémoc (or Guatemotizin) and Hernan Cortes:

In the second space the foundation is laid for a statue of Guatemotizin, the last Aztec Emperor, and in the third it is proposed to place that of Cortes his conqueror and persecutor. There is said to be not a statue or enduring effigy of Cortes... such has been the intense bitterness of the people toward the conquerors of Mexico. That they accept a proposition to erect one to his memory is proof that they are becoming civilized... ${ }^{194}$

To this day there is not a statue of Cortes next to Cuauhtémoc's monument. ${ }^{195}$ Such statues, side by side, would symbolize polarized relations between Spaniards and Aztecs. For the Porfirians the idea would have been one of association with Europe only and complete domination over Mesoamericans. The final statue would determine which people identified with Spain and those who identified with Mexico.

The Monument to Cuauhtémoc became a Porfirian image. Its image was reproduced not only on stamps but also in miniature for Mexico's exhibit at the 1889 world's fair in Paris. ${ }^{196}$ These actions extended the exposure of the monument and emphasized the person of Cuauhtémoc as the government's link to Aztec legitimacy.

The symbolism on the monument implies regional control and these images were extended to Díaz's home state, Oaxaca, also the home of the former president Juárez. Here, Díaz had a statue erected to Benito Juárez by 1909 , possibly for the

\footnotetext{
${ }^{194}$ Fredrick Ober, Travels in Mexico and Life Among the Mexicans, (Boston,: Estes and Lauriat, 1884), 350.

${ }^{195}$ It is possible that no statues of Cortes exist in Mexico. There is a gold-plated replica of an original bust is currently housed in El Museo Nacional de Historia in Chapultepec Castle in Mexico City, but I know of no others. Cortes is not considered a national hero in Mexico. This is related to the rise of indigenous pride during the revolution but the full explanation the scope of this project.

${ }^{196} \mathrm{Scott}, 350$; Tenorio-Trillo, chapter seven.
} 
1906 centennial celebration of Juárez's birthday. ${ }^{197}$ This sculpture embodies symbolic images. First, it bears the same meaning as the statue of Cuauhtémoc because the base of the statue is designed with Mixtec and Zapotec symbols and Juárez (a government official) stands above them. This imagery suggests a claim by the Porfirian government for the right to rule over the southern Mexican states. Second, there exists a duality in the person of Juárez. Since Juárez was the first Indian president of Mexico, a Zapotec from Oaxaca, he represents both the indigenous and governmental aspects of the country. Díaz fought in the war of independence from France and gained his short term legitimacy as president in 1876 from Juárez. The statue was an attempt to mold Juárez into a Porfirian symbol. ${ }^{198}$

A link between the Juárez semicircle in the Alameda, Mexico City and the statue of Juárez in Oaxaca can be found in the relationship between Juárez and Díaz. Superficially, Díaz was a fitting replacement for Juárez. He was of partial Mixtec Indian heritage from Oaxaca. He had been mentored by Juárez and had fought against the French while Juárez was president. Since the two men were not close after 1867. Díaz's legitimate line of succession required creation. ${ }^{199}$ The historian, Charles Weeks asserts about the Porfirians:

${ }^{197}$ Weeks, 43.

${ }^{198} \mathrm{My}$ comments regarding this statue and the Aztec column are based on my observation of photographs. I do not know if these pictures have been published. I examined them in the Porfirio Díaz Photograph collection at the Archivo General de Nacion. The photographs were taken by $L$. Bustamante y Cia, and titled, "Monumento a Juárez-Paseo Juárez, Oaxaca, Mexico," (Theme: Monumentos), and "Calzada Porfirio Díaz. Columna Monolitica Azteca, Oaxaca, Mexico," (Theme: Caminos, Vias y Calzadas), Series: Propiedad Artistica y Literaria, nos. 23 (1910), and 25 (1909). ${ }^{199}$ Weeks, 35. 
Recognizing the dimensions of Juárez as a national idol and praising him as a man of great courage and accomplishment, they cautiously described similarities between Juárez and Díaz by playing down the young Díaz's early opposition to Juárez and drawing the general as carrying on the task begun by his great predecessor. ${ }^{200}$

Porfirians writers were not the only ones who enacted this policy. European and American writers emphasized connections between the two men also. For example, in the biography, Diaz, Carleton Beals presented an idyllic scene where Juárez personally tended to the young Porfirio who sat at his feet. Likewise, the European, David Hannay recorded a story about Díaz rescuing Juárez's friend from a besieged bell tower in Oaxaca. ${ }^{201}$ The stories were published in 1910-1, which demonstrates that between 1885 and 1910 the administration was able to convince the outside world of Díaz's connection to Juárez if not the Mexican people. The instances that illuminate this contrived connection most clearly are the commissions for tombs and monuments to be grandly dedicated to Benito Juárez prior to and on the centennial of his birth in $1906 .^{202}$

Furthermore, an additional monument was erected in Oaxaca. On Calzada Porfirio Díaz (Porfirio Díaz Avenue) an Aztec column was mounted into a lump of mortar and stone. The placement of an Aztec artifact on a street named for Díaz in his home state underscores Díaz's determination to legitimize his regime by linking it to the Aztecs. Significantly, the monolith resembles the columns in the palace at

\footnotetext{
${ }^{200}$ Weeks, 30.

${ }^{201}$ Beals, 47; David Hannay, DIAZ. Series: Makers of the 20th Century, (NY: Henry Holt and Co., 1917), 5, 28-9.

${ }^{202}$ Weeks, 27.
} 
Mitla more than Aztec art. ${ }^{203}$ This amounts to a political usurpation of location and art. The monolith served as a political marker, a practice stretching back to the Romans who had used the placement of columns as political signifiers. ${ }^{204}$ The monolith's placement also physically rooted the Aztec presence in a part of the country that had previously remained non-centralized. Likewise, the Cuauhtémoc statue symbolically placed Mixtec/Zapotec subordination under the heroic Aztec king in Mexico City, an area where they had not been accustomed to sending tribute. The statues represent the government's desire to tailor historic figures to its benefit. The placement of the pieces represents Porfirian confidence in territorial and economic dominance.

\section{Aztec Palace}

Since reconciliation was the key term in Mexican politics, the whole cultural panorama had to do with joining pieces, with eclecticism, with pragmatic selection from whatever was available to bring the impression of homogeneity and harmony.

-Mauricio Tenorio-Trillo 205

The German intellectual, Walter Benjamin, proclaimed that "world's

exhibitions are the sites of pilgrimages to the commodity fetish." ${ }^{, 206}$ If so then the

${ }^{203}$ For a photograph of the columns at Mitla in Oaxaca see Enrique Krauze, Mistico de las Autoridad-Porfirio Diaz, Investigacion Iconographia: Aurelio de los Reyes. Series: Biographia del Poder/1, (Mexico: Fondo de Cultura Economica Tezontle, 1995), 68.

${ }^{204}$ Janson, 237. I suspect the United States had this same idea in mind when an US flag was planted on the moon.

${ }^{205}$ Tenorio-Trillo, 123.

${ }^{206}$ Walter Benjamin, "Paris, Capital of the Nineteenth Century," in Reflections: Essays, Aphorisms, Autobiographical Writings, translated by Edmund Jephcott, (New York: Schocken Books, 1978), 151. 
world's fairs in the nineteenth century served as the market place for the Porfirian advertisement of modern "civilized" Mexico.

Cuauhtémoc's monument became an international advertisement for Mexico when a miniature replica was sent to Paris for the 1889 world's fair. Mexico accepted the invitation to participate in the fair on the condition that she be granted a large space of her own and not be grouped into a generic Latin American exhibit that would deter from the grandeur of Mexico. ${ }^{207}$ Many European countries, including Germany, declined the invitation to join the fair because France was taking advantage of the event to celebrate the centennial of the French Revolution. This was France's effort to bolster its own sense of nationalism.

This was not Mexico's first or last presentation at a world's fair but the pavilion of 1889 is of interest to this study because it depended on Aztec history. Porfirio Díaz chose the design of the Aztec Palace erected by the architect Antonio Peñafiel. ${ }^{208}$ The finished product was intended to be a replica of a small Aztec teocalli. $^{209}$ The outside was adorned with six sculptured figures created by the native

\footnotetext{
${ }^{207}$ Tenorio-Trillo, 47. (Perhaps fearing that the grandeur of Mexico would be tarnished by the "backwardness of Latin America.")

${ }^{208}$ Tenorio-Trillo, 77. Carlos Pacheco assisted Diaz with the final choice of plans for the Aztec Palace.

${ }^{209} \mathrm{~A}$ teocalli is an Aztec small neighborhood temple.

${ }^{210}$ Tenorio-Trillo, 70.

${ }^{211}$ Tenorio-Trillo, 70. Emphasis mine.

${ }^{212}$ Tenorio-Trillo, 73-5.

${ }^{213}$ The Porfirian approval of the minor Aztec deity of commerce may demonstrate the malleability of these images. Within the Mexica society the merchants and their gods operated on the edge of society and traded with other cultures. The placement of this figure emphasizes the Porfirian attempt to belong to an international economic community. The Porfirians had access to the sixteenth century text, the Codex Mendoza which included an extensive list of tribute given to the Aztec empire. From this book then could come the notion that trade was extremely important to the Aztecs. The interpretation that traders existed on the edge of society and were shunned came only recently from
} 
Mexican but European trained artist, Manuel Coñtreas. Inside the palace were exhibited items relating to other indigenous tribes, other forms of art and representations of modern Mexico, including a portrait of Díaz. Significantly, the Mexicans declined the invitation to exhibit Aztec people inside the temple and to place an Indian exhibit at the foot of the Eiffel Tower. This is important because the lack of living Aztecs in the exhibit placed a higher emphasis on the ancient Aztecs who were in the Porfirian view more culturally superior to the remaining and degenerated modern Indians.

The choice of an Aztec monument instead of a different indigenous culture is understandable when we see that Aztec superiority was so heartily explained by the Porfirian administration. The writer and archaeologist, Alfredo Chavero, performed the task of writing a portion of the nationalist history, México, a Traves a del Siglos. In this book he expounded faith in the Aztec race for domestic as well as international consumption, "It would be a mistake to judge the greatness of the ancient Mexican empire by our present day Indians." 210 (Indeed, the international perspective was that they were an unclean group.) However, regarding Aztec 
dominance, Chavero considered them superior to other tribes, "Thus started gestating the three (Otomi, Nahua, and the Maya) civilizations that would develop in the course of several centuries, until the Nahua, the most perfect and powerful of the three, would expand and dominate the entire region."211 The Aztec capital became the Spanish and Mexican Capital. In the world's fairs it was not really an image of Mexico that was being transferred but Mexico City's/Tenochtitlan's authority over the nation due to its connection with the Aztecs.

Peñafiel, the architect and archaeologist who designed the Aztec Palace, considered his design to be of the "purest Aztec style" even though he incorporated carytids from the Toltec site of Tula. ${ }^{212}$ His actions reveal that it was important to emphasis the Porfirian connections to the Aztecs and that it was acceptable to mix Toltec and Aztec symbols because it was believed that the Aztecs were descendants of the Toltecs. Only through archaeology could one learn which images the Aztecs, themselves, had adopted from other cultures.

The palace built in Paris was a superficial Aztec temple adorned with neoclassical Aztec gods and heroes. The gods presented were: Centeotl; the goddess and protectress of agriculture, Tlaloc; the god of rain, his counter part, Chitlicu; the goddess of water, Xochiquetzal; the god of arts, Yacatecuhtli; the god of commerce and Camaxtli who was presented as the god of hunting. ${ }^{213}$ This pantheon reveals a focus on gods that westerners would not find repulsive. Most are connected to nature. Most importantly, these are not the gods who demand Aztec human sacrifice. 
Also presented were six historic figures who were not all Aztec but were all allies from the Valley of Mexico who represented the Nahua linguistic group. The first figure was of Itzcoatl, an Aztec King, the second was of Nezahualcoyotl, the poet King of Texcoco. The third sculpture was of the allay King Totoquihuatzin of the Tepanacs. The next two reliefs represented Cacama and Cuitlahuac not just by name but in form. ${ }^{214}$ Lastly, Cuauhtémoc was placed in the pantheon of leaders and gods. ${ }^{215}$ The sculptures were wrought by Jesus Contreras when he was only twentythree years old. The beautification of the Aztecs and their gods is evidenced by their clothing. (Clothing was a mark by which Indian cultures were often judged. ${ }^{216}$ ) The Gods each wore a robe or dress such as those found on marble Greek and Roman figures but all were from bronze, in keeping with the modern times. ${ }^{217}$

The palace's outer structure was easily mocked in a political cartoon titled, Nuestra Fachada en Paris (Our Facade in Paris) by Jesús Martínez Carreón. This cartoon was published in the opposition newspaper El Hijo de Ahuizote. ${ }^{218}$ The one frame cartoon depicts the entrance into the palace. On the original balcony Contreras had placed Peñafiel's Toltec caryatid forms. In the exhibit they held up the portico in the same way that the six female figures upheld the portico at the sites in Athens known as the "Porch of the Maidens" and the "Treasury of the Siphanians" in the

${ }^{214}$ These two names also appear on the base of the Monument to Cuauhtémoc.

${ }^{215}$ Tenorio-Trillo, 77.

${ }^{216}$ William Beezley, "Mexican Satre on the Zócalo: Nicolás Zúniga y Miranda," in The Human Tradition in Latin America: The Nineteenth Century, edited by William Beezley and Judith Ewell, (Wilmington, Delaware: Scholarly Resources, 1989), 208.

${ }^{217}$ Tenorio-Trillo, chapter one.

${ }^{218}$ First published on 4 August 1889. My source is Krauze, Porfirio: El Poder, 42. 
Sanctuary of Apollo at Delphi. ${ }^{219}$ In the political cartoon, Porfirio Díaz is characterized as a caryatid. Díaz's approval and power alone enabled the construction of the palace. Written on his feet are the reminders, "Plan de Tuxtepec" and "Re-election." These symbolize the president's hypocrisy because by 1889 he was supposed to relinquish power according to his campaign program established by the "Plan de Tuxtepec." However, Díaz maintained the presidency an additional twenty-one years. The carytids uphold six major images of Porfirian administrators with critical labels and instead of the Aztec idols that border the Aztec palace the cartoon placed two other administrators.

Above the original facade is a replica of a round Aztec stone, probably the Aztec Calendar Stone which became a nationalist icon after Porfirio Díaz dedicated it into the National Museum of Anthropology. In the cartoon spoof the round stone above the facade bears the image of Porfirio with a crown, holding a club in his left hand. This is probably a reference to his method of ruling by "pan o malo" [bread or the club]. The title, Our Facade in Paris, plays with the word "facade." The literal meaning is a reference to the front of the Aztec Palace but the deeper meaning is that the Aztec palace failed to serve as a nationalist image and impressed no one with its amalgamation of European and Aztec images. It was considered a poor front for a developing country.

219 Janson, 164. The "Porch of the Maidens" is located at the Erechtheum, Acropolis in Athens and dates to $420 \mathrm{BC}$. The site at Delphi dates to $525 \mathrm{BC}$. 
If the outside of the palace was not pure Aztec style, neither was the inside.

The inner decor, created by the French designer, E. Rousseau, resembled a French or Viennese palace. ${ }^{220}$ Rousseau abandoned his attempts to base the inside on Aztec designs because no one knew what the inside of an Aztec imperial or religious dwelling looked like. ${ }^{221}$ Instead, the inner room was occupied by paintings, sculptures and artifacts made by contemporary artists.

One example of an artifact would be the preserved head of an Apache Indian. Although visitors were appalled by the Aztec motifs, they were fond of the head. According to Mauricio Tenorio-Trillo, one American reporter recorded, "with emotion but without surprise, seeing 'the head of an Apache chief admirably conserved."

The preservation of an Indian corpse was not entirely unknown at the time. For example, also in 1889 at the "Anthropological Exhibition" in Munich, were exhibited the perfectly preserved mummies of "the hairy woman" Julia Pastrana and her baby. Pastrana, a Mexican Digger Indian, had died twenty-nine years earlier giving birth to the same baby. Her unscrupulous husband, who had exhibited her in side shows during her life, due to her physical deformities and extreme hairiness, exhibited her in death as well. ${ }^{222}$

${ }^{220}$ Tenorio-Trillo, 78.

${ }^{221}$ Tenorio-Trillo, 78-9.

${ }^{222}$ Fredrick Drimmer. Very Special People: The Struggles, Loves and Triumphs of Human Oddities, (New York: AMJON Publishers Inc., 1973), 372-374. 
The Apache head was more than a curiosity for the Porfirian administration.

It was a symbol of political power; it was a warning that Díaz controlled the frontier because the modern Mexican nation was stronger than the savage northern Indians. This is the symbol of the Porfirians ability to "strengthen the national element on the frontier." 223 This exhibit could have been placed specifically for the benefit of the United States who withheld official recognition of Díaz's regime under the excuse that, to the Texan's disadvantage, Mexico was not doing enough to combat Indians in their northern frontier. ${ }^{224}$ The irony is that although the head brings to mind London Bridge and Aztec skull racks it represents the Porfirian will to win control of its northern and southern borders.

The exterior of the palace was intended to link the Porfirian administration to Aztec greatness and legitimacy and the interior was designed for this same goal. Exhibited were paintings from the official Academy of San Carlos in Mexico City. Two of the paintings chosen were painted during the occupation of the French in $1865{ }^{225}$ These paintings were both commissioned by the prosperous mestizo, Sancho Solis, and depicted Indians in European social structures. ${ }^{226}$ Regarding the two paintings Tenorio-Trillo remarked,

These two paintings were emblematic of an official sanction of the Indian past. As with the facade of the Aztec Palace, the paintings sought to order,

${ }^{223}$ See footnote no. 21 .

${ }^{224}$ For more information see Daniel Cosio Villegas, The United States Versus Porfirio Diaz, translated by Nettie Lee Benson, (Lincoln: University of Nebraska Press, 1963). The controversy along the frontier is one of the main themes of this title.

${ }^{225}$ Maximilian was a supporter of the arts and funded the academy in those years.

${ }^{226}$ Tenorio-Trillo, 112. 
classify and civilize knowledge of the Indian past in such a way as to make it accessible and worthy of respect. ${ }^{227}$

These two paintings represent Indians through European styles. El Senado de Tlaxcala (The Senate of Tlaxcala) was probably chosen for display because it portrays the ancient Tlaxcala Indians within the structure of a democracy. In the painting, the nobles of Tlaxcala debate weather or not the tribe ought to ally with the Spanish or the Aztecs in the on coming fight. The men are sitting in a half circle that resembles the Roman senate. The art historian, Stacie Widdifield, asserted that, “...the device of the Roman senate keeps the Indians orderly and lawful within that zone."228 The painting removes the community leaders from their own political context and places them within a physical structure (semi-circle) that is identifiable and respectable to westerners. Clearly, this painting and its placement at the world's fair represent an attempt to sanitize the image of Mexican Indians.

Another piece in the Aztec palace was a miniature replica of the Monument to Cuauhtémoc. Its presence emphasizes my earlier comments that the Porfirians saw this statue as a cleaner version of history with which they were not ashamed to link themselves politically.

The effort to cleanse the image of the Aztecs and then use them as nationalist symbols at the world's fairs was fruitless in 1889 because foreigners refused to view the Aztecs as a classical culture. Some visitors thought the ruins were a not very advanced and therefore revealed the barbarity of the Aztecs and the Mexicans. The

\footnotetext{
${ }^{227}$ Tenorio-Trillo, 119.

${ }^{228}$ Widdifield, 103.
} 
visitors saw a difference between the ancient Greek and Roman ruins and the Mexican ruins. They simply did not think that the Aztecs had a classical era. ${ }^{229}$ Others were offended by the teocalli which they thought was a sacrificial temple. Others saw similarities between the authoritarian Aztecs and Porfirians. ${ }^{230}$ Eventually, the Aztec Palace was considered a failure that expressed nationalism and modernity poorly. After it was dismantled it was never reassembled in Mexico and the plans to resurrect it to serve as an archaeological museum rusted like the steel of which it was constructed. ${ }^{231}$

To emphasis their heritage from the old world the Porfirians constructed European style buildings. The Monument to Cuauhtémoc and the Aztec Palace illustrate that in order to create links to antiquity the administrators molded the image of the Aztec warrior into a Greek citizen. These symbols granted Díaz's administration legitimacy because they created a line of succession between the ancient Aztecs and the Porfirians. The inheritance was geographic and economic dominance in the Valley of Mexico. The ideal, exerted symbolically through the placement of monuments in Oaxaca, would be the extension of that power to the edges of Mexico.

\footnotetext{
${ }^{229}$ Tenorio-Trillo, 95.

${ }^{230}$ Tenorio-Trillo, 93-95.

${ }^{231}$ Tenorio-Trillo, 93-95.
} 


\section{CHAPTER FIVE}

\section{CREATING NATIONAL AND “INTERNATIONAL PERSONALITY 232}

\section{A. PORFIRIO DÍAZ}

"A Prince need not necessarily have all the good qualities I mentioned above, but he should certainly appear to have them...if he only appears to have them they will render him service."

$-{ }_{-233}^{23 i c c o l o ~ M a c h i a v e l l i ~}$

As Machiavelli stated, appearances are important for rulers. This is why I will now turn to examine the activities of Porfirio Díaz regarding the dedications of public monuments and the symbolic cleansing of archaeological artifacts. This process established him as the Valley of Mexico's philosophical and military leader.

The first event attended by Porfirio Díaz, meant to promote the incorporation of Aztec images into Mexican pride was the dedication of the Monument to Cuauhtémoc. This event was garnished with fanfare and attended by the president's entourage. This group included the pro-indianist archaeologist and historian, Alfredo Chavero. This ceremony provided an official indoctrination of the Aztec history into the Porfirian past. The speeches made by both Chavero and Díaz glorified and condoned the Aztec King, Cuauhtémoc, as a brave warrior. ${ }^{234}$ Cuauhtémoc, became a Mexican hero because the government wanted him to.

\footnotetext{
${ }^{232}$ Sierra believed that during the Porfiriato Mexico gained its, "international personality," Hale, 10.

${ }^{233}$ Niccolo Machiavelli, The Prince, translated by George Dull, (Great Britain: Penguin Group, 1961), 100.

${ }^{234}$ Tenenbaum, 139.
} 
Díaz further developed the Aztec theme by ordering the indoctrination of the Aztec Calendar Stone into the National Museum in $1886 .{ }^{235}$ The stone, had been erected on top of one of the main Aztec temples at the time of Spanish arrival in Tenochtitlan. On the orders of the Bishop of Montufar, the stone was buried shortly after 1569 and forgotten until $17900^{236}$ In that year when it was accidentally rediscovered again, the clergy tried again to manipulate the artifact by hiding it but they were not completely successful. ${ }^{237}$ The Calendar Stone was mounted to the Metropolina Catedral by the order of the "art-loving and liberal Viceroy, Revillagigedo" who ordered that it be exposed. ${ }^{238}$ Díaz's willingness to induct the controversial stone into the anthropology museum meant that he determined the presentation of the piece. It became representative of a time when the Aztecs were still numerically capable but could not pose a threat to Díaz's government. Additionally, Díaz was pulling the stone into a government sanctioned location that he had provided with greater funding in $1876 .{ }^{239}$ By doing so he created a public location for his appropriations and symbolic meanings.

Díaz also manipulated the use of the Aztec images through the independence celebrations and the promotions for it. Although 1910 is remembered as the official

${ }^{235}$ Zelia Nuttall, 1886, "Mexico," American Journal of Archaeology, vol. 2, part 2, 100. and Carlos Nararrete, La Piedra del Sol, (Mexico: Edimex, 1968), 5.

${ }^{236}$ Valentini, 12.

${ }^{237}$ Esther Pasztory, Aztec Art. New York: Harry N. Abrams, Inc., Publishers, 1983. 140. For this statement she cited Antonio Leon Y Gama, Descripcion Historica y Cronologica de las Dos Piedras gue con Ocasion del Nuevo Empedrado que se sete formando en la Plaza Principal de Mexico se Hallaron en ella en el año 1790. Mexico City: Imprenta de Felipe Zuniga y Ontiveros, 1972.

${ }^{238}$ Valentini, 12.
${ }^{239}$ Keen, 416. 
start of the Mexican Revolution, Porfirio Díaz had probably intended that it be remembered for the grandeur and lavish independence celebrations.

The image of the Indian pervaded the centennial fiestas. In the parades men dressed like Indians and danced "traditional" movements. ${ }^{240}$ Indians were present on the federal stamp commemorating independence and most importantly, Teotihuacan, an Indigenous archaeological site was inaugurated as a national monument.

On September 16, 1910 a long parade marched its way through the capital. Newsreels show a group of men dressed as Aztec warriors, resembling those in the Codex Mendoza as they pass by Porfirio Díaz. ${ }^{241}$ It is important that "Aztec costumes" were suddenly meriting government approval rather than Maya costumes because this demonstrates the government's emphasis on the Nahua cultures. Additionally, a government sponsored national parade is a somewhat controlled environment and the placement of Aztec dancers here reveals the administrations desire to link itself to Aztec history.

This approval was carried into print. "De Independencia A Porfiriato," the federal stamp issued to commemorate the anniversary bears five pictures. First, in the bottom left hand corner is a drawing depicting the Aztec foundation myth. A group of contemporary peasants look on as an eagle carries a serpent in his mouth. Above this appears the Virgin of Guadalupe. In the upper right hand corner the

${ }^{240}$ Tony Essex (producer), The Ragged Revolution: The Romance and Reality of the Mexican Revolution, narrated by Alec Mango, (London: Yorkshire Television Productions, 1982); Kurt Ross, Codex Mendoza: Aztec Manuscript, (Fribourg: Productions Liber, 1978), 100-110.

${ }^{241}$ Essex. 
French are being driven from Chapultepec Castle and below that is a portrait of Porfirio Díaz mounted on a horse. ${ }^{242}$ The Angel of independence upholds the center of the stamp. Only the image of the virgin is not directly related to a war for autonomy. However all the images are essentially Mexican and it is the mixing of the Indian and European that make these images proper for a stamp commemorating independence. The melding of the Aztec eagle with contemporary peasants and the image of the Virgin of Guadalupe who is a mixture of the Catholic Mary and the Aztec earth goddess, Coatlicue ${ }^{243}$ brings the indigenous element to the stamp. It also brings forth a period prior to independence and stretching back to the Mexica settlement on the island of Tenochtitlan. ${ }^{244}$

Another preparation for the celebrations was the commissioning of photographers to document colonial architecture, indigenous ruins, and monuments. Guillermo Kahlo, was hired by the administrator, José Ives Limantour to document Mexico for a picture book. ${ }^{245}$ Kahlo, a Jewish Hungarian raised in Germany, worked so fastidiously that he earned the title of the "first official photographer of Mexico's cultural patrimony." Although his business card advertised, "Guillermo Kahlo, specialist in landscapes, buildings, interiors, factories, etc." he occasionally

${ }^{242}$ The original portrait still hangs in Chapultepec Castle.

${ }^{243}$ Clendinnen, 198.

${ }^{244}$ Conrrado Padilla, Photograph- "De Independencia a Porfiriato," Series: Propiedad Artistica y Literaria, theme: Postales Historica, no. 1, commissioned by Instruccion Publica y Bellas Artes, 1910, Archivo General Nacional.

${ }^{245}$ Guillermo Kahlo was the father of the famous portraitist Frida Kahlo. 
photographed portraits of Díaz's administrators and family members. ${ }^{246}$ In essence, Kahlo became the national photographer because his photographs captured the infrastructure of Aztec and Porfirian society. These examples provide the evidence that the Aztec image was used gregariously throughout the urban celebrations.

Thus far this chapter has discussed only the celebrations in Mexico City but the Valley of Mexico served as a location for the celebrations as well. Díaz participated in the Congreso Internacional visit to Teotihuacan and allowed the national archeologist, Leopoldo Batres to name caves at the site after him. Batres is credited with approaching Díaz with the idea of excavating the largest temple in the ancient city of Teotihuacan (just 30 miles from Mexico City) for the purpose of having it stand as a nationalist symbol if the work could be finished in time for the centennial celebrations. To encourage Díaz's support Batres gave the president a tour of Teotihuacan and named specific caves after Díaz. ${ }^{247}$ It was on this visit with the Congreso, on September 15 1910, that Díaz performed the inaugural ceremony of this temple known to the Aztecs as the Pyramid of the Sun. ${ }^{248}$ A great deal of activity occurred in the years prior to the celebrations. The excavation of the temple and the trip by the Congreso Internacional were part of those activities designed to

${ }^{246}$ This information regarding Guillermo Kahlo can be found in the biography on his daughter, Hayden Herrera, Frida: A Biography of Frida Kahlo, (New York: Harper and Row, Publishers, 1983), 7. Herrera culled her information from several articles written in the 1940's about Guillermo's art.

${ }^{247}$ Tompkins, 199.

${ }^{248}$ Batres, Congreso Internacional de Americanistas, 1910, minutes, 29. 
impress scholars with the modernity of the Mexican technology and the antiquity of Aztec culture. ${ }^{249}$

Porfirio Díaz purchased this pyramid for himself. ${ }^{250}$ His purchase of the Temple of the Sun meant that Díaz owned the mythical birthplace of the Aztec gods; additionally, he owned what was to become the Mexican national symbol. In essence, Díaz owned Mexico, past and present. ${ }^{251}$

Furthermore, Díaz gave his name to Aztec knowledge. A codex, an Aztec book, was named after the president. The Codex Porfirio Díaz, currently housed in the Porfirio Díaz archives, is unusual because generally these pre-Hispanic or sixteenth century texts were named after religious figures, libraries or the scholars who deciphered them.

The hands-on manipulation of artifacts by Batres and symbolically by Díaz allowed them to improve the images of Indians and by association themselves. Batres' displays in the museum determined the public's perception of Mexico's ancient past. Díaz, played the symbolic game by purchasing the pyramid and ordering the

${ }^{249}$ Congreso Americanistas, 1910. Batres hoped that the visitors would be impressed not only by the technology he used to excavate the temple but also by the new train ride to the site.

${ }^{250}$ The rumor that Díaz purchased the Temple of the Sun is recorded in a Mexicana Airlines brochure from January 1996. As the brochure did not state its source for this information I realize that it may be inaccurate but it does not matter if this was true, only that ownership remains a perpetual symbol of Díaz's ultimate authority.

${ }^{251}$ The notion that owning Mexican symbols means owning the country continues today. The alleged medallion of the famous eighteenth century Mexican poet, Sor Juana Iñes de la Cruz, was found three years ago. The director of the convent kept it hidden from public and scientific eyes in her own home. She was accused of abusing her position of power in order to own Mexico. The Mexican intellectual, Homero Aridjis, commented, "It's now become a tradition in Mexico for many public figures not only to take control of the public treasury but of the culture of the nation as well, (Anthony De Palma, "The Poet's Medallion: A Case of Finders Keepers?," New York Times, 15 December, 1995, A4). 
placement of the Aztec Calendar Stone with his personal dedication. By doing this he demonstrated a pride in Aztec technology and art and also maintained control over where the stone would be and who would have access to it. Ownership of the Temple of the Sun would let him determine its presentation to the public.

All of these activities amount to Porfirio Díaz's attempt to link both himself and his administration to the legitimate reign of the Aztecs and the Toltecs before them. Díaz's purchase of the pyramid at Teotihuacan was one more act that enabled him to take control of the budding national "culture" that his administration defined. Symbolically the government controlled the Aztec past by appropriating their knowledge (calendars, books) and more importantly the birthplace of their gods.

\section{B. PORFIRIOPOXTLI}

A political cartoon, published in 1900 in the opposition paper, El Hijo del Ahuizote reveals criticism of Díaz's contradictory policies regarding indigenous people. In this piece titled, Un Ofrenda Porfiriopoxtli (The Offering to the Black God Porfirio) the artist, Jesús Martínez Carreón, sarcastically portrayed Díaz as a Mayan/Aztec God who is receiving human sacrifices. Díaz's countenance is detailed in a generic Maya stele approximately $21 / 2$ meters high. $^{252}$

His name, Porfiriopoxtli, is a corrupted version of any Aztec god whose name ends in "tli," including Huitzilopoctli, the Aztec war god who demanded human

${ }^{252}$ Stele's were stone tablets used by the Mayas to record the lives of rulers. 
sacrifice. The ending, "tli," means black. ${ }^{253}$ Below his face his name is labeled in mock Mayan glyphs and then translated into Spanish as dictadura (dictator).

The offering to Porfiriopoxtli is given by a Porfirian administrator, who is identifiable by his long pointed mustache, beard and aged face. The administrator is dressed in the robes and the sparse headpiece of an Aztec priest and king. Perhaps he is Moctezuma, who was known for his intellect, religiosity and kingship. The sacrifices are three human males who each represent different indigenous groups engaged in warfare with the Porfirian government. The priest/king sacrifices the Maya, the Yaqui and the Tomechic (from Sonora) people. The offering in the administrator's hands is a smoking heart labeled patriatismo (patriotism). The contemporary reader is to understand that the administration is sacrificing the tribes for the benefit of the nation. The metaphor of Aztec human sacrifice reveals the brutality of the campaign process because Mexicans and Europeans viewed human sacrifice strictly as savagery and satanic adoration not as a separate religion.

This cartoon reveals to us that Díaz was successful in his efforts to identify himself and his administration with Aztec nobility but he was never able to uplift the image of the Aztec people higher than their reputation as bloodthirsty savages.

When others wished to criticize him they were able to do so simply by accepting his identification with the Aztecs and raising it against him. ${ }^{254}$ Perhaps this cartoon was

\footnotetext{
${ }^{253}$ Bierhorst, 358.

${ }^{254}$ This cartoon may be found in the picture book edited by: Enrique Krauze and Fausto
} Zeron-Medina, Porfirio: El Poder, (Editorial Clio: Mexico City, 1993), 46. It was originally published in El Hijo del Ahuizote, 29 April 1900. 
inspired by the "Aztec Palace" built at the world's fair in 1889 because the frame draws parallels between the Porfirian and Aztec authoritarian governments, a popular criticism of the Aztec Palace. ${ }^{255}$

The cartoon also demonstrates that even at this early date, 1900 , political views were that Díaz was both manipulating and sacrificing the Indigenous people of Mexico. It is not surprising then that the rebellion which sent him into exile was composed of mestizo troops. Faced with the task of establishing state, nation and loyalty as quickly as possible, Díaz and his administrators followed an established path and blazed another. For an established criteria of government they looked to Europe, particularly France where ideas were both old and modern, traditional and progressive. They used the European models made for glorifying the ancients. ${ }^{256}$ The Mexican government claimed heritage not only from the Spaniards but also from the Greeks, the Romans and uniquely from the Aztecs. Internationally, this was an original maneuver. To claim the heritage of the indigenous peoples was considered barbaric. The European and American audiences were not impressed by the images.

Within Mexico, however, it was obvious that the Porfirians owed their legitimacy to the Aztecs and the Toltecs before them. This was how power was symbolically transferred in the Valley of Mexico. It is also why critics found it was hypocritical and unacceptable on a humane level but acceptable on a political level.

${ }^{255}$ See Tenorio-Trillo, chapter five, for criticisms of the Aztec Palace.

${ }^{256}$ For information regarding the process by which the French and the Prussians invented traditions and turned statues into national monuments see Eric Hobsbam, "The Nation as Invented Tradition," in Nationalism, edited by John Hutchinson and Anthony D. Smith, (Oxford: Oxford University Press, 1994), 76-83. 
Like Díaz, the Aztecs had been the most interested in economic and military dominance. 


\section{CHAPTER SIX}

\section{CONCLUSION}

Faced with an immediate need to establish his government Porfirio Díaz strove for economic stability and international recognition. Díaz used the Monument to Cuauhtémoc to test the domestic political atmosphere. He received support from Justo Sierra and Alfredo Chavero but then made the mistake of constructing an Aztec temple for the 1889 world's fair. International opinion declared the Aztec to be the "Iroquois of the South"; effectively the Aztecs did not escape their reputation. The exhibit reinforced the attitude that the Aztecs barbarity superseded their civility. Despite the amalgamation of Aztec and classical images on the temple the European audience found it reprehensible.

Deriving a profitable national symbol from Aztec history was a difficult process. It required obtaining the images and altering them for use. In their raw forms they were confusing and essentially too Indian. The Porfirians highlighted the qualities that resembled European history while concealing less appealing qualities. The modification of the image enabled its use but did not guarantee its international success.

The Porfirians claimed political legitimacy in the Valley of Mexico because they altered the image of the Aztec just as the Aztecs had done with the history of the 
Toltecs. This occurred not only in Mexico but in Europe as well. German scholars extrapolated modern culture from the height of Greek civilization. ${ }^{257}$ The Porfirians saw that they could blend the cultural symbols of ancient Europe and America, thereby stripping the Aztec images of their meanings and negative connotations.

This process meant to symbolically establish Díaz as the leader of a world class country. As the political successor of the Aztecs he gained their symbols and economic and territorial domain. When the administrators housed the artifacts in museums and absorbed the native image into public art they utilized the indigenous meanings of dominance but contained actual power to the modern government. The symbolic usurpation of the Aztec authority gave the Porfirians what they needed, supreme authority in the valley and the right to extend the Aztec empire. ${ }^{258}$ By 1910, the military controlled the northern and eastern regions of Mexico. Even the Aztecs had contended with rebellions when they overstepped their territorial authority. Moctezuma's city fell when the enemies of the Aztecs stopped paying tribute and started fighting with the Spaniards. Just when Díaz finally extended the empire beyond the valley he went into exile. His regime faded but the Monument to Cuauhtémoc still stands on the Paseo de la Reforma. It is the image of the Old World tangled with the new. 


\section{BIBLIOGRAPHY}

\section{PRIMARY SOURCES}

Barrett, John and Francisco J. Yanes (Director and Assistant Director). MEXICO: A General Sketch. Compiled by the Pan American Union: Washington DC, 1911.

Batres, Leopoldo. "El cascabel de la culebra mitologica de Teotihuacan." Boletin de la Sociedad de Geografia, 1890. 199-201.

-------Contestacion a la Duplica del Sr. Lic. Alfredo Chavero: En la Controversia de Monolito de Coatlinchan. Series: Documentos para la Historia de Mexico, Vol. 11. Mexico: Fidencio S. Soria, 1905.

-Datos Arqueológico. Barcelona, (anonymous publisher), 1911. 1-3.

-"Descubrimientos y consolidación de los monumentos arqueológicos de Teotihuacan." Congreso Internacional de Americanistas. 1912. 188-193.

------La Isla de Sacrificios: La Señora Zelia Nuttall de Piñard y Leopoldo Batres. Mexico: Tipografia Económica, 1910.

1910. "Las ruinas de Xochiacalco." Congreso Internacional de Americanistas XVII. Mexico: Museo Nacional de Arqueologia Historia y Etnologia.

El Sr. Lic. Alfredo Chavero Y El Monolito de Coatlinchan. Mexico: Fidencio S. Soria, 1904.

----Teotihuacan: Memoria. Mexico: Fidencio Soria, 1906.

-Teotihuacan O la Ciudad Sagrada de los Toltecas. Mexico: Talleras de la escula Nacional de Artes y Oficios Ex-Convento de S. Lorenze.

Blichfeldt, E.H. A Mexican Journey. Chautauqua, NY: Chautauqua Press, 1919.

Boban, E. "Personal Communication" (Letter to Porfirio Díaz). No. 0136681. New York: 20 December 1886. Archivo Porfirio Díaz de la Universidad IberoAmericana. Unpublished.

Bustamante y Cia, L. Photograph, "Calzada Porfirio Díaz. Columna Monolitica Azteca, Oaxaca, Mexico." Series: Propiedad Artistica y Literaria. Theme: 
Caminos, Vias y Calzadas, no 25. Commissioned by Instruccion Publica y Bellas Artes, 1909. Archivo General Nacional de Mexico.

------Photograph, "Monumento a Juárez-Paseo Juárez, Oaxaca, Mexico." Series: Propiedad Artistica y Literaria. Theme: Monumentos, no 23. Commissioned by: Instruccion Publica y Bellas Artes, 1910. Archivo General Nacional de Mexico.

Case, Alden Buell. Thirty Years with the Mexicans. New York: Fleming Revell Company, 1917.

Charney, Désiré. Letter to Porfirio Díaz. From Paris, No. 012599. 28 November 1887. Archivo Porfirio Díaz de la Universidad IberoAmericana. Unpublished.

Chavero, D. Alfredo. México A Traves de los Sigios: Historia Antigua y de la Conquista. vol 1, nos. 1-2. Mexico D.F.: Gustavo S. Lopez and Justo Sierra, 1889.

Educational Company. The Complete Portfolio of Photographs of the World's Fair, St. Louis, 1904: The Sights, Scenes and wonders of the Fair Photographed: World's Progress Illustrated---A Grand Panoramic View of the Fair in all It's Glory---The Strange People of the World in Pictures. Chicago: The Educational Company, 1904.

Prescott, William Hickling. The History of Mexico. New York: Bantam Books, 1853, reprint 1964.

Hrdlicka, Ales. "Differences Between White and Colored Kids." American Anthropologist, 1909. 347-57.

Krauze, Enrique. Místico de las Autoridad-Porfirio Díaz, Investigacion Iconographia: Aurelio de los Reyes. Series: Biographia de Poder/1. Mexico: Fondo de Cultura Económica Tezontle, 1995. and Fausto Zeron-Medina. Porfirio: El Destierro. Editorial Clio: Mexico City, 1993.

Porfirio: El Poder. Editorial Clio: Mexico City, 1993.

Porfirio: El Derrumbe. Editorial Clio: Mexico City, 1993.

MacCurdy, George. "An Aztec 'Calendar Stone' in the Yale University Museum." American Anthropologist. Vol. 12, \#4, Oct-Dec, 1910. 481- 
Morgan, Henry Lewis. Montezuma's Dinner: An Essay on the Tribal Society of North American Indians. New York: Labor News Company, reprinted in 1950.

Nararrete, Carlos. La Piedra del Sol. Mexico: Edidmex, 1968.

Nichols, Benito and Edward and George W. Orrin, Guide to Orrin Bro's and Nichols' Aztec Fair: Mexico Past and Present. Orrin Bros. and Nichols, 1886.

Nuttall, Zelia. "Aztecs and Predecessors in the Valley of Mexico," En Miscelanea. Mexico D.F.: Instituto Nacional de Antropologia y Historia, 1926. 245-255.

--“Island of Sacrificios." American Anthropologist. vol. 12, 1910. 277-295.

“Mexico.” American Journal of Archaeology. vol. 2, part 2, 1886. 100.

Ober, Fredrick A. Travels in Mexico and Life Among the Mexicans. Boston: Estes and Lauriat, 1884.

Padilla, Conrrado. Photograph, "De Independencia a Porfiriato." Series: Propiedad Artistica y Literaria. Theme: Postales Historicas, no.1. Commissioned by: Instruccion Publica y Bellas Artes, 1910. Archivo General de la Nacion.

Posada, José Guadelupe. Mexican Popular Prints. Boston: Shambala Redstone Editions, 1993.

Quantity Postcards. Photograph, "The Aztec Girls." San Francisco: Quantity Postcards, 1987.

----Photograph, "Pip and Flip: Twins from the Yucatan with World Circus Side Show, Coney Island.“ San Francisco: Quantity Postcards, 1992.

Rocha. Letter of recommendation to Porfirio Díaz. No. 004922. 21 May 1885. Archivo Porfirio Díaz de la Universidad IberoAmericana. Unpublished.

Seler, Eduardo. “Ancient Mexican Feather Ornaments." Mexican and Central American Antiquities, Calendar Systems and History. Translated by Charles P. Bowditch. Washington DC: Government Printing Office, 1893, 1904. "Similarity of Design of some Teotihuacan Frescoes and Certain Mexican Pottery Objects." Congreso de Americanistas, 1912. 194-201. 
Sierra, Justo. The Political Evolution of the Mexican People. Translated by Charles Ramsdell. Austin: The University of Texas Press, 1969.

Scott. Scott's 1995 Standard Postage Stamp Catalogue, 151 Edition Bol. 4:

European Countries and Colonies, Independent Nations of Africa, Asia, Latin America, J-Q. Sidney Ohio: Scott Publishing Co., 1994.

Stephens, John Lloyd. Incidents of Travel in the Yucatan, vol I and II. Mérida: Producción Editorial Dante.

Thompson, Edward H. The People of the Serpent: Life and Adventure Among the Mayas. Boston: The Riverside Press Cambridge, 1932.

-_-_-_Atlantis: Not a Myth,” Popular Science Quarterly, 51. October 1879. 75964.

Valentini, Philip J.J. “The Mexican Calendar Stone." Proceedings of American Antiquarian Society. Worcester: Press of Charles Hamilton, 1879.

\section{SECONDARY SOURCES}

Aaberg, Stephen and Joy Bonsignore, "A Consideration of Time and Labor Expenditure in the Construction Process at the Teotihuacan Pyramid of the Sun and Poverty Point Mound." Three Papers on MesoAmerican Archaeology: Contributions of the University of California Archaeological Research Facility. Berkeley: University of California. No. 24, 1975.

Alexander, Caroline. "Troy's Prodigious Ruin," Natural History. April, 1996. 4251.

Benjamin, Walter. Reflections: Essays, Aphorisms, Autobiographical Writings. Translated by Edmund Jephcott. New York: Schocken Books, 1978.

Beals, Carleton. Porfirio Díaz: Dictator of Mexico. Philadelphia: J.B. Lippincott Co., 1932.

Beezley, William. "Mexican Satre on the Zócalo: Nicolás Zúniga y Miranda," in The Human Tradition in Latin America: The Nineteenth Century. Edited by William Beezley and Judith Ewell. Wilmington, Delaware: Scholarly Resources, 1989. 
Bernal, Ignacio. A History of Mexican Archaeology: The Vanished Civilization of Middle America. Translated by Ruth Malet. Great Britain: Thames and Hudson, 1980.

Berrin, Kathleen. "Reconstructing Crumbling Walls: A Curator's History of the Wagner Murals Collection." Feathered Serpents and Flowering Trees: Reconstructing the Murals of Teotihuacan. Ed by Berrin. Hong Kong: The Fine Arts Museums of San Francisco, 1988..

Bierhorst, John. Nahuatl-English Dictionary and Concordance to the Cantares Mexicanos. Stanford University Press, 1985.

Blumberg, Arnold. "The Diplomacy of the Mexican Empire, 1863-67." Transactions of the American Philosophical Society held at Philadelphia for Promoting Useful Knowledge New Series, Vol. 61, Part 8, 1971. 67-106.

Bogdan, Robert. Freak Show: Presenting Human Oddities for Amusement and Profit. Chicago: University of Chicago Press, 1988.

Brenner, Anita. The Wind that Swept Mexico: The History of the Mexican Revolution, 1910-1942: Historical Photos. Assembled by George R. Leighton. Series: Texas-Pan American. Austin: University of Texas Press, 1971.

Brunhouse, Robert L. In Search of the Maya. Albuquerque: University of New Mexico Press, 1973.

-In Pursuit of the Ancient Maya: Some Archaeologists of Yesterday. Albuquerque: University of New Mexico Press, 1975.

Clendinnen, Inga. Aztecs: An Interpretation. NY: Cambridge University Press, 1991.

Cobb, Roger W., and Charles D. Elder. The Political Uses of Symbols. New York: Longman, 1983.

Coe, Michael. Breaking the Maya Code. Slovenia: Thames and Hudson, 1992.

Coggins, Clemency Chase and Orrin C. Shane III. edited Cenote of Sacrifice: Maya Treasures from the Sacred Well at Chichén Itzá. Austin: University of Texas Press, 1984.

Cosio Villegas, Daniel. The United States Versus Porfirio Diaz. Translated by Nettie Lee Benson. Lincoln: University of Nebraska Press, 1963. 
Craig, Gordon A. Germany: 1866-1945. New York: Oxford University Press, 1978.

De Palma, Anthony. "The Poet's Medallion: A Case of Finders Keepers?" New York Times, 15 December 1995.

De Saules, Janet. Getting to Know Spain and Spanish. Great Britain: Times Four Publishing Ltd, 1993.

Douglas, Preston. "Fossils and the Folsom Cowboy." Natural History. Vol. 106, no 1, Feb 1997. 16-22

Drimmer, Fredrick. Very Special People: The Struggles, Loves and Triumphs of Human Oddities. New York: AMJON Publishers Inc., 1973.

Duel, Leo. Conquistadors Without Swords: Archaeologists in the Americas, an Account with Original Narratives. New York: St. Martin's Press, 1989.

Elder, Rita. "The Icons of Power and Popular Art." Mexican Monuments: Strange Encounters. Arranged by Helen Escobedo with photographs by Paolo Gori. NY: Abbeville, 1989. 64-77.

Fairly, William. Edited Monumentum Ancyranum: The Deeds of Augustus. Fairley, Philadelphia: The Department of History at the University of Pennsylvania, 1898.

Fernández, Justino. El Arte del Siglo XIX en el Museo. Mexico: Universidad Nacional Autonoma, 1952.

Galeano, Eduardo. Memory of Fire: Faces and Masks, vol. II. Translated by Cedric Belfrage. New York: Pantheon Books, 1987.

Gillespie, Susan D. The Aztec Kings: The Construction of Rulership in Mexica History. Tucson: The University of Arizona Press, 1989.

Graves, Robert. The White Goddess: A Historical Grammar of Poetic Myth. New York: Farrar, Strauss and Giroux, 1980.

Hale, Charles. Transformation of Liberalism in Late Nineteenth-Century Mexico. Princeton: Princeton University Press, 1989.

Hannay, David. Diaz. Series: Makers of the 20th Century. New York: Henry Holt and Co., 1917. 
Herrera, Hayden. Frida: A Biography of Frida Kahlo. New York: Harper and Row, Publishers, 1983.

Hobsbam, Eric. "The Nation as Invented Tradition." in Nationalism. Ed by John Hutchinson and Anthony D. Smith Oxford: Oxford University Press, 1983, 1994. 76-83.

Hu-DeHart, Evelyn. "Pacification of the Yaquis," The Age of Porfirio Díaz: Selected Readings. Edited by Carlos B. Gil. Albuquerque: University of New Mexico Press, 1977. 129-139.

Yaqui Resistance and Survival: The Struggle for Land and Autonomy, 18211910. Madison: University of Wisconsin Press, 1984.

Katz, Friedrich. The Secret War in Mexico: Europe, the United States, and the Mexican Revolution. Chicago: University of Chicago Press, 1981.

Keen, Benjamin. The Aztec Image in Western Thought. New Jersey: Rutgers University Press, 1971.

Janson, H.W. History of Art, Fourth Edition. Revised by Anthony F. Janson. New York: Harry Abrams, Inc., 1991.

Jones, Lindsay. Twin City Tales: A Hermeneutical Reassessment of Tula and Chichén Itzá. Photographs by Lawrence G. Desmond. Boulder: University Press of Colorado, 1995.

Lange, Charles H. and Carroll L. Riley. Bandelier: The Life and Adventures of Adolf Bandelier, American Archaeologist and Scientist. Salt Lake City: University of Utah Press, 1996.

Lear, John. "Mexico City: Space and Class in the Porfirian Capital, 1884-1910." Journal of Urban History, vol. 22, \#4, May 1996. 454-492.

Lockhart, James and Stuart B. Schwartz. Early Latin America: A History of Colonial Spanish America and Brazil. New York: Press Syndicate of the University of Cambridge, 1983.

Machiavelli, Niccolo. The Prince. Translated by George Dull. Great Britain: Penguin Group, 1961.

Marchand, Suzanne L. Down from Olympus: Archaeology and Philhellenism in Germany, 1750-1970. Princeton: Princeton University Press, 1996. 
Matos Moctezuma, Eduardo. Teotihuacan. New York: Rizzoli International Publication Inc. 1990.

Meyer, Karl. Teotihuacan. New York: Newsweek Book Division, 1973.

Meyer, Michael and William L. Sherman. The Course of Mexican History, 4th edited New York: Oxford University Press, 1991.

Monsivais, Carlos. "On Civic Monuments and Their Spectators." Mexican Monuments: Strange Encounters. Arranged by Helen Escobedo with photographs by Paolo Gori. New York: Abbeville, 1989. 105-128

Nunn, Fredrick M. The Time of the Generals: Latin American Professional Militarism in World Perspective. Lincoln: University of Nebraska Press, 1992.

O'Neill, John B. The Metropolitan Museum of Art: The Pacific Islands, Africa and the Americas. New York: Branford D. Kellehr, 1987.

Pasztory, Esther. Aztec Art. New York: Harry N. Abrams, Inc. Publishers, 1983.

Preston, Douglas, "Fossils and the Folsom Cowboy." Natural History. Vol 106, no 1, Feb. 1997. 16-22.

Reed, Nelson. The Caste War of Yucatan. Stanford: Stanford University Press, 1964.

Sullivan, Paul. Unfinished Conversations: Mayas and Foreigners Between Two Wars. (New York: Knopf, 1989.)

Tenenbaum, Barbara. "Streetwise History: The Paseo de la Reforma and the Porfirian State, 1876-1910." Rituals of Rule, Rituals of Resistance: Public Celebration and Popular Culture in Mexico." Edited by W.H. Beezley, C.E. Martin and W.E. French. Wilmington, Delaware: Scholarly Resources Inc, 1994. 127-150.

Tenorio-Trillo, Mauricio. Mexico at the World's Fairs: Crafting a Modern Nation. Berkeley: University of California, 1996.

Tompkins, Peter and Hugh Harleston, Jr. Mysteries of the Mexican Pyramids: Dimensional Analysis on Original Drawings. New York: Harper and Row, 1976. 
Tucker, William H. The Science and Politics of Racial Research. Urbana: University of Illinois Press, 1994.

Van Young, Eric. "Conclusion: The State as Vampire-Hegemonic Projects, Public Ritual and Popular Culture in Mexico, 1600-1990. Rituals of Rule, Rituals of Resistance: Public Celebration and Popular Culture in Mexico. Edited by W.H. Beezley, C.E. Martin and W.E. French. Wimington, Delaware: Scholarly Resources Inc., 1994. 344-374.

Vuelo: Mexican, Ejemplar coleccionable de cortesia. Mexico: Medio Publicitario Impresos, January, 1996.

Weeks, Charles A. The Juárez Myth of Mexico. Alabama: The University of Alabama Press, 1987.

Wittlin, Alma S. The Museum: Its History and its Tasks in Education. London: Routledge and K. Paul, 1949.

Widdifield, Stacie G. The Embodiment of the National: In Late Nineteenth-Century Mexican Painting. Tucson: The University of Arizona Press, 1996. 


\section{APPENDIX:}

Gallery of Portraits: Biographies

Batres, Leopoldo. Díaz's brother in law. National Inspector and Conservator of Archaeological Monuments, 18841911.

Blichfeldt, E.H. Traveler to Mexico, 190911.

Charney, Désiré. A French explorer who noticed the structural similarities between Teotihuacan and Chichén Itzá. Traveled Mexican archaeological sites with Díaz in 1859.

Chavero, Alfredo. Author, anthropologist, and archaeologist. Wrote volume one of the national history, concerned with the pre-Columbian peoples of Mexico, 1889. Promoted a positive image of the Aztecs. Opposed Batres.

Contreras, Jesus. Mexican sculpture trained in Europe. Designed the historical sculptures on the Aztec Palace in 1889.

Cortes, Hernan. Spanish conquistador who ordered the destruction of the Aztec City, Tenochtitlan, 1521. 
Cuauhtémoc. The last Aztec King. He was tortured by the Spanish and hung on the order of Cortes.

Díaz, Porfirio. Served as a solider in the war against the French. Overthrew President Tejada and served as Mexico's president from 18761880. and 18841911. Second Indian president Exiled to Europe by the Mexican Revolution.

Maximilian Von Hapsburg, Ferdinand. Emperor of Mexico during the French invasion. Executed in 1868.

Juárez, Benito. Lawyer. First Indian president of Mexico. Exiled during the French Intervention. Returned in 1868.

Le Plongeon, Augustus. French Amateur archaeologist who excavated in the Yucatan in 1876. He found a chac mol which was confiscated by the Mexican government when he tried to send it to the United States.

Maudslay, Alfred P. British amateur archaeologist who worked in the Yucatan. Opposed Batres. 
Nuttall, Zelia. Anthropologist, archaeologist, professor of the University of California, honorary professor at the National Museum in Mexico City. Opposed Batres.

Ober, Fredrick. Visitor to Mexico, 1876-1884.

Peñafiel, Antonio. Archaeologist, architect. Designer of the Aztec Palace for the 1889 World's Fair in Paris.

Seler, Edward. Prussian anthropologist responsible for the classification of the National Museum in Mexico City prior to 1910 . Reputed to be an expert.

Sierra, Justo. Minister of Public Instruction and the Fine Arts. Wrote a romantic history of Mexico. Promoted the use of Indigenous images as national symbols. Ally of Batres.

Thompson, Edward. An American consulate to Mexico who purchased the hacienda of Chichén Itzá and dredged the sacred cenote for signs of human sacrifice. He stayed in Mexico from 1900-1930. 